\title{
Bibliografia comentada sobre medicalização do parto no Brasil, 2001-2017
}

\author{
Annotated bibliography on the medicalization \\ of childbirth in Brazil, 2001-2017
}

\section{Wanda Weltman \\ Bibliotecária. \\ Rio de Janeiro - RJ - Brasil \\ wandawel@msn.com}

Recebido em 28 set. 2017 Aprovado em 8 jan. 2018.
WELTMAN, Wanda. Bibliografia comentada sobre medicalização do parto no Brasil, 2001-2017. História, Ciências, Saúde - Manguinhos, Rio de Janeiro, v.25, n.4, out.-dez. 2018, p.1083-1127.

Resumo

Bibliografia comentada sobre a medicalização do parto no Brasil, no período de 2001 a 2017. Reúne artigos publicados em periódicos brasileiros, recuperados nas bases Scielo, Hisa e Lilacs. Apresenta as referências dos artigos, seguidas de resumos dos autores. Seu objetivo é mapear o que foi produzido, no período, no campo da medicalização do parto no país, a fim de tornar essa produção mais acessível a estudantes e pesquisadores interessados na temática.

Palavras-chave: bibliografia; medicalização do parto; parto; Brasil.

\section{Abstract}

An annotated bibliography on the medicalization of childbirth in Brazil from 2001 to 2017. It includes articles published in Brazilian periodicals retrieved from the Scielo, Hisa, and Lilacs databases. The references from the articles are presented, followed by the authors' abstracts. The aim is to map out what was written about the medicalization of childbirth in Brazil in the period in question in order to make this scholarly output more accessible to students and researchers interested in the subject.

Keywords: bibliography; medicalization of childbirth; childbirth; Brazil. 
$\mathrm{E}$ sta bibliografia é dedicada à temática da medicalização do parto no Brasil no período de 2001 a 2017. Ela foi pensada como uma homenagem à historiadora e pesquisadora feminista brasileira Maria Lúcia de Barros Mott, que publicou na revista Estudos Feministas (v.10, n.2, 2002) a "Bibliografia comentada sobre a assistência ao parto no Brasil (19722002)", incluída no dossiê "Parto", organizado por ela naquele número da publicação (Lago, Tornquist, 2011).

Maria Lucia de Barros Mott nasceu em 1948. Vinte anos depois, começou o curso de história na Universidade de São Paulo (USP). Segundo Lago e Tornquist (2011), as indefinições da juventude a levaram a interromper por vários anos sua graduação, para viajar por diversos países e se dedicar a diferentes atividades. Em 1976, Mott retornou ao Brasil e começou a trabalhar na Fundação Carlos Chagas, passando a se assumir como feminista e pesquisadora (Lago, Tornquist, 2011). Três anos depois concluiu sua graduação. Sem mesmo fazer mestrado, ingressou no doutorado em história social na USP, onde defendeu, em 1988, a tese Parto, parteiras e parturientes, Madame Durocher e sua época (Mott, 1998). De 1999 a 2000, Maria Lucia completou sua formação com um pós-doutorado na Escola de Enfermagem da Universidade de São Paulo (Tsunechiro, Riesco, Oguisso, 2011).

Maria Lucia fez parte do comitê editorial da revista Estudos Feministas desde a sua criação, em 1992, até 1994 (período no qual a revista foi editada pelo Ciec/ECO/UFRJ) (Lago, Tornquinst, 2011), e trabalhou em diversas instituições de pesquisa, entre elas, o Instituto de Saúde da Secretaria de Saúde de São Paulo (2004-2009) e o também paulista Instituto Butantan (2009-2011). No âmbito da rede de pesquisa Patrimônio Cultural da Saúde, instituída pela Casa de Oswaldo Cruz, coordenou a equipe de São Paulo, que produziu, entre 2007 e 2009, um levantamento das instituições de saúde de São Paulo desde a Colônia até meados do século XX. Tal pesquisa resultou no livro História da saúde em São Paulo: instituições e patrimônio arquitetônico, da coleção História e Patrimônio da Saúde, publicado em outubro de 2011 (Mott, Sanglard, 2011).

Maria Lucia Mott destacou-se como historiadora no campo dos estudos feministas, com contribuições importantes para os estudos sobre mulheres. Sua tese de doutorado levou-a ao estudo das parteiras e da transformação dessa atividade no contexto de medicalização do parto. De forma semelhante, seu pós-doutorado a conduziu aos estudos sobre a trajetória da enfermagem no Brasil. Seus estudos também se mostram uma importante contribuição à história da saúde. Nesse campo, vários subtemas foram explorados em diversos trabalhos, a saber: estudos sobre assistência ao parto e as profissões relacionadas ao nascimento a respeito de instituições de saúde e personagens relevantes para a história do setor e acerca de diferentes aspectos da formação em saúde. Além disso, sua trajetória intelectual inclui pesquisas sobre escravidão. Maria Lucia faleceu em 26 de junho de 2011, em decorrência de um câncer de pulmão.

Nada melhor que as palavras de sua colega Ana Paula Vosne Martins para definir um pouco do perfil dessa historiadora.

Os traços da personalidade e a forma como Maria Lúcia se relacionava com as pessoas e o mundo podem ajudar a entender como ela se direcionou para certas áreas da investigação histórica, abrindo novas frentes de pesquisa, descobrindo acervos documentais ou então lançando outro olhar sobre acervos já conhecidos ou pouco explorados. 
Tratar da sua relação com o fazer histórico talvez seja a melhor maneira de homenageála ... Maria Lúcia foi uma historiadora militante, porque sempre esteve comprometida com a produção do conhecimento histórico, bem conduzida do ponto de vista teórico e metodológico. Seus temas de pesquisa tinham uma dimensão social e política inegável ao tratar dos 'recônditos do mundo feminino' (Martins, 2013, p.1047; destaques no original).

Esta nova bibliografia, além de homenagear Maria Lucia, constitui um instrumento que possibilitará aos estudantes e profissionais interessados pelo tema o mapeamento do que tem sido produzido, mais recentemente, no campo da medicalização do parto no Brasil. Diferentemente do primeiro trabalho, não temos como objeto a assistência ao parto. De forma diversa, e em conformidade com o projeto de pesquisa a que este texto se filia, temos como foco a medicalização do parto. Tal escolha implicou novos critérios de busca de artigos. O levantamento feito por Mott incluiu dissertações, teses, livros, capítulos e outras publicações, solicitadas aos próprios autores. Neste trabalho, em virtude do maior amadurecimento do campo de pesquisas, a busca limitou-se a bases de dados eletrônicas, restringindo-se, portanto, a artigos produzidos em revistas científicas.

O levantamento dos artigos constantes da presente bibliografia foi feito entre junho e agosto de 2017, por meio de buscas em três bases de dados on-line. As bases pesquisadas foram: (a) Scielo (Scientific Electronic Library Online), base de periódicos científicos e eletrônicos coordenada pela Fapesp/CNPq/Bireme/Opas/OMS; (b) Hisa (Base Bibliográfica em História da Saúde Pública na América Latina e Caribe), base bibliográfica desenvolvida pela Biblioteca da Casa de Oswaldo Cruz/Fiocruz, com apoio da Opas e da Bireme; e (c) Lilacs (Literatura Latino-Americana e do Caribe em Ciências da Saúde), base de dados cooperativa do Sistema Bireme. A escolha dessas bases deveu-se à sua importância para as áreas de ciências da saúde, ciências humanas e sociais, campos de conhecimento nos quais o tema da medicalização do parto se insere. O resultado da pesquisa apontou para a preponderância de artigos na base Scielo, embora tenham sido recuperados artigos em todas as três bases.

A estratégia de buscas utilizada associou o tema "Parto" com o local "Brasil" e o período de 2001 a 2017. Definiu-se que seriam incluídos na bibliografia apenas artigos de periódicos e, entre esses, somente os que se configurassem como artigos originais, frutos de pesquisa e revisões de literatura. Após o levantamento inicial, foram selecionados 187 artigos referentes aos diversos aspectos do processo de medicalização do parto. Na apresentação foram incluídos os resumos dos trabalhos, quando necessário, de forma editada, ou acrescido de informações do corpo do artigo. Cabe ressaltar que há temas não contemplados na atual bibliografia que são também caros e importantes para o campo dos estudos sobre gravidez e nascimento no Brasil - aspectos médicos da gravidez e do nascimento, estudos antropológicos sobre atuação das parteiras em diferentes comunidades, trabalhos epidemiológicos etc. -, e espera-se que venham a ser objeto de futuras bibliografias. Os artigos estão apresentados em ordem alfabética, para facilitar a consulta. 


\section{REFERÊNCIAS}

LAGO, Mara Coelho de Souza; TORNQUIST, Carmen Susana.

Maria Lucia de Barros Mott: pesquisadora militante. Revista Estudos Feministas, v.19, n.2, p.634-636. 2011.

MARTINS, Ana Paula Vosne.

Uma historiadora militante: Maria Lúcia Mott (1948-2011). Cadernos de Pesquisa, v.43, n.150, p.1.042-1.053. 2013.

MOTT, Maria Lucia.

Bibliografia comentada sobre a assistência ao parto no Brasil. Revista Estudos Feministas, v.10, n.2, p.493-507. 2002.
MOTT, Maria Lucia.

Parto, parteiras, parturientes: mme. Durocher e sua época. 1998. Tese (Doutorado) Universidade de São Paulo, São Paulo. 1998.

MOTT, Maria Lúcia; SANGLARD, Gisele (Org.). História da Saúde em São Paulo: instituições e patrimônio arquitetônico (1808-1958). São Paulo: Manole. 2011.

TSUNECHIRO, Maria Alice; RIESCO, Maria Luiza Gonzalez; OGUISSO, Taka.

Maria Lucia Mott e a parceria com a enfermagem e a obstetrícia. Cadernos de História da Ciência, v.7, n.2, p.111-115. 2011. 
1. ALMEIDA, Cristiane Andréa Locatelli de; TANAKA, Oswaldo Yoshimi. Perspectiva das mulheres na avaliação do Programa de Humanização do Pré-Natal e Nascimento. Revista de Saúde Pública, v.43, n.1, p.98-104. 2009. Disponível em: <http://www.scielo.br/scielo.php?script=sci_arttext\&pid=S0034-89102009000100013\&lng $=p t \& n r m=i s o \& t \operatorname{lng}=p t>$. Acesso em: 11 set. 2017.

- Analisa a importância da inclusão da perspectiva das mulheres na avaliação do Programa de Humanização do Pré-Natal e Nascimento. Estudo qualitativo realizado em base de dados primários coletados para a avaliação do Programa de Humanização do Pré-Natal e Nascimento, do Ministério da Saúde, em 2003, em sete municípios das cinco regiões do Brasil, selecionados a partir de dados extraídos de sistemas de bancos de dados oficiais já existentes. Conclui que a inclusão da perspectiva da usuária pode permitir que determinadas normatizações do programa sejam flexibilizadas, adequando-se às particularidades dos diferentes grupos de gestantes em diferentes comunidades.

2. ALVES, Valdecyr Herdy; ALVES, Pedro Manuel Santos; PADOIN, Stela Maris de Mello. A tecnicização e a prática do cuidado ao parto: uma abordagem fenomenológica a partir de Husserl. Texto \& Contexto - Enfermagem [online], v.25, n.3. 2016. Disponível em: <http://www.scielo.br/scielo.php?script=sci_arttext\&pid=S0104$07072016000300601 \&$ Ing=pt\&nrm=iso\&tlng=pt>. Acesso em: 16 set. 2017.

- Reflete sobre o parto como um processo clínico centrado sobre sua dimensão biológica. Tem como base inspiradora a filosofia fenomenológica de Husserl, a matematização da natureza e a tecnicização da relação do ser humano com o mundo. Conclui afirmando a importância de pensar as ciências da saúde e a enfermagem a partir das contribuições da fenomenologia

3. AMARAL, Marivaldo Cruz do. Mulheres, imprensa e higiene: a medicalização do parto na Bahia (1910-1927). História, Ciências, Saúde - Manguinhos, v.15, n.4, p.927-944. 2008. Disponível em: <http://www.scielo.br/ scielo.php?script=sci_arttext\&pid=S0104-59702008000400003\&lng=pt\&nrm=iso\&tlng=pt>. Acesso em: 28 ago. 2017.

- Discute a inserção da imprensa leiga como veículo de disseminação da agenda higienista na cidade de Salvador, Bahia, em princípios do século XX. Os alvos dos articulistas foram o parto medicalizado e os novos padrões de atenção ao corpo feminino e aos recém-nascidos. A Maternidade Climério de Oliveira contou com o apoio irrestrito da imprensa, que não poupou esforços para apresentar esse espaço como ideal para o parto hospitalar.

4. ANDREUCCI, Carla Betina; CECATTI, José Guilherme. Desempenho de indicadores de processo do Programa de Humanização do Pré-natal e Nascimento no Brasil: uma revisão sistemática. Cadernos de Saúde Pública, v.27, n.6, p.1.053-1.064. 2011. Disponível em: <http://www.scielo.br/scielo.php?script=sci_arttext\&pid=S0102311X2011000600003\&lng=pt\&nrm=iso\&tlng=pt>. Acesso em: 12 set. 2017.

- Reúne os dados nacionais sobre o acompanhamento pré-natal, utilizando o Sisprenatal ou outras fontes de informação. Trata-se de uma revisão sistemática, com busca eletrônica de artigos no Medline, Embase e Scielo. Compilaram-se publicações a partir de 2001 que utilizaram os indicadores de processo do PHPN. Os indicadores de processo apresentaram incremento ao longo do período, mas o Sisprenatal registra baixa cobertura do PHPN quando comparado com outras fontes de informação.

5. ANGULO-TUESTA, Antonia; GIFFIN, Karen; GAMA, Andréa de Sousa; D'ORSI, Eleonora; BARBOSA, Gisele Peixoto. Saberes e práticas de enfermeiros e obstetras: cooperação e conflito na assistência ao parto. Cadernos de Saúde Pública, v.19, n.5, p.1.425-1.436. 2003. Disponível em: <http://www.scielo.br/scielo. 
php?script=sci_arttext\&pid=S0102-311X2003000500021\&lng=pt\&nrm=iso\&tlng=pt>. Acesso em: 22 ago. 2017.

- Busca compreender as representações de obstetras e de enfermeiras sobre o trabalho em equipe. Analisa de que forma as dimensões de poder, cooperação e conflito e autonomia técnica são permeadas por concepções dualistas que influem na organização e qualidade da atenção à parturiente.

6. BARBOSA, Gisele Peixoto; GIFFIN, Karen; ANGULO-TUESTA, Antonia; GAMA, Andrea de Souza; CHOR, Dóra; D'ORSI, Eleonora; REIS, Ana Cristina Gonçalves Vaz dos. Parto cesáreo: quem o deseja? Em quais circunstâncias? Cadernos de Saúde Pública, v.19, n.6, p.1.611-1.620. 2003. Disponível em: <http://www.scielo.br/scielo.php?script=sci_ arttext\&pid=S0102-311X2003000600006\&lng=pt\&nrm=iso\&tlng=pt>. Acesso em: 22 ago. 2017.

- Investiga a existência de uma "cultura de cesárea", ou preferência por este tipo de parto, por meio de uma amostra, em duas maternidades do município do Rio de Janeiro. Mostra que quanto maior o intervalo de tempo entre a admissão no hospital e o parto, mais frequente é a solicitação. Conclui que a maioria das mulheres não quer e não pede cesárea; ou seja, não existe uma "cultura" feminina que valorize a cesárea como preferência. Além do desejo da laqueadura, as circunstâncias concretas da assistência no pré-parto/parto parecem influenciar no pedido da mulher.

7. BARRETO, Maria Renilda Nery. Assistência ao nascimento na Bahia oitocentista. História, Ciências, Saúde - Manguinhos, v.15, n.4, p.901-925. 2008. Disponível em: <http://www.scielo.br/scielo.php?script=sci_ arttext\&pid=S0104-59702008000400002\&lng=pt\&nrm=iso\&tlng=pt>. Acesso em: 8 set. 2017.

- Aborda as culturas de assistência ao parto na Bahia oitocentista e trabalha com a hipótese de que, em Salvador, coexistiram duas culturas obstétricas: a dos médicos-parteiros, que faziam uso dos recursos técnicos e cognitivos disponibilizados pela obstetrícia como especialidade médica, e a das tradicionais parteiras, cujo saber era de natureza empírico-sensorial. Enfoca os segmentos sociais e profissionais que atuaram na assistência ao parto; o papel da Faculdade de Medicina da Bahia na formação e certificação das parteiras; e a utilização dos periódicos como meio de legitimação dos médicos-parteiros, ao mesmo tempo que problematiza a pequena participação das parteiras nesses veículos de comunicação.

8. BARROS, Lena Maria; SILVA, Raimunda Magalhães da. Atuação da enfermeira na assistência à mulher no processo de parturição. Texto \& Contexto - Enfermagem, v.13, n.3, p.376-382. 2004. Disponível em: <http:// www.scielo.br/scielo.php?script=sci_arttext\&pid=S0104-07072004000300006\&lng=pt\&nrm=iso\&tlng= pt>. Acesso em: 5 set. 2017.

- Analisa a atuação da enfermeira de centro obstétrico na assistência à mulher no processo de parturição. É um estudo de campo do tipo descritivo, realizado em quatro maternidades públicas de São Luís (MA), de abril a julho de 2002. Participaram do estudo 21 enfermeiras de centros obstétricos. A partir da técnica de análise de conteúdo, evidencia que a enfermeira de centro obstétrico atua junto à mulher com ações diretas e passivas (observando, protegendo); indiretas (administrando) e com participação mais efetiva, tomando decisões e influenciando sua ação e seu comportamento (oferecendo cuidado solidário e obstétrico).

9. BASSO, Joéli Fernanda; MONTICELLI, Marisa. Expectativas de participação de gestantes e acompanhantes para o parto humanizado. Revista Latino-Americana de Enfermagem, v.18, n.3, p.390-397. 2010. Disponível em: <http://www.scielo.br/scielo.php?script=sci_arttext\&pid=S0104-11692010000300014\&lng=pt\&nrm=is o\&tlng=pt>. Acesso em: 11 set. 2017.

- Identifica expectativas de participação de gestantes e acompanhantes para o parto humanizado, tendo como suporte teórico-metodológico a pedagogia libertadora. Conclui que, apesar de as interações vivenciadas dentro das instituições de saúde serem permeadas por relações de poder, práticas educativas libertadoras podem contribuir para o fortalecimento dos sujeitos rumo à superação desse status quo e para a transformação da realidade obstétrica. 
10. BATISTA, Luís Eduardo; RATTNER, Daphne; KALCKMANN, Suzana; OLIVEIRA, Maridite Cristóvão Gomes de. Humanização na atenção à saúde e as desigualdades raciais: uma proposta de intervenção. Saúdee Sociedade, v.25, n.3, p.689-702. 2016. Disponível em: <http://www.scielo.br/scielo.php?script=sci_arttext\&pid=S0104$12902016000300689 \&$ lng=pt\&nrm=iso\&tlng=pt $>$. Acesso em: 15 set. 2017.

- Relata a proposta de ação/intervenção e humanização do parto e nascimento: questões étnico/ racial e de gênero, desenvolvida no Hospital Geral de São Mateus Dr. Manoel Bifulco, em São Paulo (SP), que objetivou sensibilizar a equipe do hospital para a mortalidade materna de mulheres negras. O projeto teve como resultados a inclusão do quesito "cor" na Autorização de Internação Hospitalar; a sensibilização da equipe para as especificidades da saúde da mulher negra; e a mudança de percepção da equipe em relação à presença do pai na hora do nascimento, gerando a campanha "Pai não é visita".

11. BERQUÓ, Elza; LAGO, Tania Di Giacomo do. Atenção em saúde reprodutiva no Brasil: eventuais diferenciais étnico-raciais. Saúde e Sociedade, v.25, n.3, p.550-560. 2016. Disponível em: <http://www.scielo.br/scielo. php?script=sci_arttext\&pid=S0104-12902016000300550\&lng=pt\&nrm=iso\&tlng=pt>. Acesso em: 15 set. 2017. - Compara indicadores da atenção à saúde reprodutiva das mulheres negras e brancas. São utilizadas informações obtidas na Pesquisa Nacional de Demografia, Saúde da Criança e da Mulher. Pesquisa domiciliar por amostragem probabilística complexa com representatividade nacional. Permite inferência para cinco macrorregiões, incluindo o contexto urbano e rural. Foram estudadas 14.625 mulheres brancas e negras. Na análise bivariada, mulheres negras, com menor escolaridade, pior classe econômica e não portadoras de plano de saúde apresentaram desfechos mais desfavoráveis. No entanto, após análise multivariada, as diferenças entre brancas e negras perderam significância estatística. Conclui que desigualdades sociais e econômicas mantêm-se determinantes das iniquidades na atenção em saúde reprodutiva.

12. BEZERRA, Maria Gorette Andrade; CARDOSO, Maria Vera Lucia Moreira Leitão. Fatores culturais que interferem nas experiências das mulheres durante o trabalho de parto e parto. Revista Latino-Americana de Enfermagem, v.14, n.3, p.414-421. 2006. Disponível em: <http://www.scielo.br/scielo.php?script=sci_arttext\&pid=S0104$11692006000300016 \&$ Ing=pt\&nrm=iso\&tlng=pt>. Acesso em: 24 ago. 2017.

- Analisa os fatores que interferem nas experiências vividas pela parturiente. Para coleta e análise dos dados foi utilizada a etnoenfermagem. A prática do cuidado cultural na assistência à mulher mostrou como é importante a comunicação e o respeito às suas crenças e valores no momento do trabalho de parto e parto.

13. BEZERRA, Maria Gorette Andrade; CARDOSO, Maria Vera Lúcia Moreira Leitão. Fatores interferentes no comportamento das parturientes: enfoque na etnoenfermagem. Revista Brasileira de Enfermagem, v.58, n.6, p.698-702. 2005. Disponível em: <http://www.scielo.br/scielo.php?script=sci_arttext\&pid=S0034$71672005000600013 \&$ Ing=pt\&nrm=iso\&tlng=pt>. Acesso em: 6 set. 2017.

- Analisa o comportamento das gestantes em trabalho de parto e parto. Participaram sete parturientes que tiveram filhos por parto normal em uma maternidade pública de Fortaleza, Ceará. O método de pesquisa utilizado para a coleta e análise dos dados foi a etnoenfermagem. Concluiu-se que são vários os fatores que subsidiam o comportamento da mulher na vivência do trabalho de parto e parto e que a assistência dos profissionais de saúde deve estar sempre voltada para o cuidado humanístico, unindo o saber cultural ao científico.

14. BRENES, Anayansi Correa. História do parto e seus cuidados. LPH - Revista de História, ano 12, n.12, p.167-176. 2002. Disponível em: <http://lph.ichs.ufop.br/sites/default/files/lph/files/lph_revista_12.pdf?m=1499107119>. (pdf). Acesso em: 17 set. 2017.

- Apresenta a mesa-redonda que destaca a figura de Mme. Durocher como a primeira parteira formada pela faculdade do Rio de Janeiro e a primeira mulher reconhecida pela Academia Imperial de Medicina, no século XIX. Aborda o destino da escola de partos de Paris e o conflito parteiras/parteiros pelo mundo. 
15. BRÜGGEMANN, Odaléa Maria; OSIS, Maria José Duarte; PARPINELLI, Mary Angela. Apoio no nascimento: percepções de profissionais e acompanhantes escolhidos pela mulher. Revista de Saúde Pública, v.41, n.1, p.44-52. 2007. Disponível em: <http://www.scielo.br/scielo.php?script=sci_arttext\&pid=S0034$89102007000100007 \&$ Ing=pt\&nrm=iso\&tlng=pt>. Acesso em: 8 set. 2017.

- Descreve a percepção de profissionais da saúde sobre prestar assistência à parturiente na presença do acompanhante por ela escolhido e a percepção dos acompanhantes sobre essa experiência. Estudo qualitativo, a partir de ensaio clínico randomizado controlado. Empregouse a técnica de análise temática de discurso, utilizando-se as figuras metodológicas: ideia central, expressões-chave e o discurso do sujeito coletivo. Conclui que os profissionais da saúde consideraram importante o apoio do acompanhante, não tendo sido observado problema em prestar assistência na sua presença.

16. BRÜGGEMANN, Odaléa Maria; PARPINELLI, Mary Angela; OSIS, Maria José Duarte. Evidências sobre o suporte durante o trabalho de parto/parto: uma revisão da literatura. Cadernos de Saúde Pública, v.21, n.5, p.1.3161.327. 2005. Disponível em: <http://www.scielo.br/scielo.php?script=sci_arttext\&pid=S0102-311X2005000 $500003 \& \operatorname{lng}=p t \& n r m=i s o \& t$ lng $=p t>$. Acesso em: 6 set. 2017 .

- Apresenta revisão dos estudos sobre os efeitos do suporte à mulher durante o trabalho de parto/parto, enfocando as principais características, o provedor de suporte, a simultaneidade na presença ou não do companheiro/familiares da parturiente durante o trabalho de parto e parto e os resultados obtidos. Foram incluídos os estudos publicados entre os anos de 1980 e 2004, que contemplam explicitamente os aspectos avaliados. De maneira geral, os resultados do suporte são favoráveis, destacando-se redução da taxa de cesarianas, da analgesia/medicamentos para alívio da dor, da duração do trabalho de parto, da utilização de ocitocina e produzindo aumento na satisfação materna com a experiência vivida. Quando o provedor de suporte não é um profissional de saúde, os benefícios têm sido mais acentuados.

17. BUSANELLO, Josefine; KERBER, Nalú Pereira da Costa; MENDONZA-SASSI, Raúl Andrés; MANO, Patrícia de Souza; SUSIN, Lulie Rosane Odeh; GONÇALVES, Bruna Goulart. Atenção humanizada ao parto de adolescentes: análise das práticas desenvolvidas em um centro obstétrico. Revista Brasileira de Enfermagem, v.64, n.5, p.824-832. 2011. Disponível em: <http://www.scielo.br/scielo.php?script=sci_arttext\&pid=S0034$71672011000500004 \&$ Ing=pt\&nrm=iso\&tlng=pt>. Acesso em: 30 ago. 2017.

- Analisa as práticas desenvolvidas na assistência à adolescente, a partir do relato dos trabalhadores de um centro obstétrico de um hospital universitário, com base na proposta de humanização do parto do Ministério da Saúde. Segundo os trabalhadores, estão sendo desenvolvidas práticas úteis na assistência ao parto, dentre as quais as orientações sobre formas de relaxamento no trabalho de parto, o incentivo ao vínculo entre mãe e filho e a amamentação.

18. CANASSA, Neli Silvia Andreazzi; BORENSTEIN, Miriam Süsskind; BRÜGGEMANN, Odaléa Maria; GREGÓRIO, Vitória Regina Petters. O saber/fazer das parteiras na Maternidade Carmela Dutra de Florianópolis (SC) [1967/1994]. Revista Brasileira de Enfermagem, v.64, n.3, p.423-430. 2011. Disponível em: <http://www.scielo.br/scielo. php?script=sci_arttext\&pid=\$0034-71672011000300003\&lng=pt\&nrm=iso\&tlng=pt>. Acesso em: 12 set. 2017. - Pesquisa qualitativa com abordagem sócio-histórica. Objetiva historicizar os saberes e fazeres das parteiras na Maternidade Carmela Dutra de Florianópolis (SC) no período de 1967 a 1994. Os dados foram coletados por meio de entrevistas semiestruturadas com quatro parteiras e categorizados com base na análise de conteúdo. Os resultados evidenciaram que as parteiras adquiriram seu saber no cotidiano da prática e em curso regular realizado em outra maternidade da capital. Esses saberes permitiram oferecer cuidados junto às mulheres durante o trabalho de parto, parto, no pós-parto e aos recém-nascidos.

19. CARDOSO, Junia Espinha; BARBOSA, Regina Helena Simões. O desencontro entre desejo e realidade: a "indústria" da cesariana entre mulheres de camadas médias no Rio de Janeiro, Brasil. Physis: Revista de 
Saúde Coletiva, v.22, n.1, p.35-52. 2012. Disponível em: <http://www.scielo.br/scielo.php?script=sci_ arttext\&pid=S0103-73312012000100003\&lng=pt\&nrm=iso\&tlng=pt>. Acesso em: 13 set. 2017.

- A pesquisa qualitativa busca compreender, por meio da percepção de mulheres de camadas médias, o desencontro entre o desejo pelo parto vaginal e o desfecho em cesariana. Os resultados evidenciaram a interferência do obstetra na escolha das mulheres, influenciando o desfecho em cesariana. Conclui que, para muitas mulheres, não está sendo possível escapar das "armadilhas" de um modelo biomédico mercantilizado, interventor e iatrogênico, institucionalizado e legitimado pela sociedade.

20. CARNEIRO, Rosamaria Giatti. Dilemas antropológicos de uma agenda de saúde pública: Programa Rede Cegonha, pessoalidade e pluralidade. Interface - Comunicação, Saúde, Educação, v.17, n.44, p.49-59. 2013. Disponível em: <http://www.scielo.br/scielo.php?script=sci_arttext\&pid=S1414-32832013000100005\&lng $=p t \& n r m=i s o \& t$ lng $=p t>$. Acesso em: 14 set. 2017.

- Discute o Programa Rede Cegonha à luz de duas possibilidades interpretativas e a partir de tensões como medicina $\mathrm{x}$ despersonalização e saúde $\mathrm{x}$ doença, e de noções de pessoa, corpo, experiência e singularidade na contemporaneidade.

21. CARNEIRO, Rosamaria. Daquilo que os médicos quase não falam: transe êxtase na cena de parto. Experiências e percepções dissidentes de saúde e de bem-estar na contemporaneidade. Ciência \& Saúde Coletiva, v.18, n.8, p.2.369-2.378. 2013. Disponível em: <http://www.scielo.br/scielo.php?script=sci_arttext\&pid=S1413$81232013000800021 \&$ lng=pt\&nrm=iso\&tlng=pt>. Acesso em: 14 set. 2017.

- Discute experiências e percepções de mulheres adeptas de outros modos de parir que não a cesárea e como esses modos de parir têm desalojado a prática médica da "biopolítica". Analisa as impressões e atitudes dessas mulheres à luz da lógica das intensidades e dos afetos, de novos modos de subjetivação e da possibilidade de outras moralidades, que não mais a da histeria e a da fragilidade dos corpos das mulheres.

22. CARON, Olga Aparecida Fortunato; SILVA, Isilia Aparecida. Parturiente e equipe obstétrica: a difícil arte da comunicação. Revista Latino-Americana de Enfermagem, v.10, n.4, p.485-492. 2002. Disponível em: <http:// www.scielo.br/scielo.php?script=sci_arttext\&pid=S0104-11692002000400004\&lng=pt\&nrm=iso\&tlng= pt>. Acesso em: 4 set. 2017.

- Descreve a comunicação entre os profissionais que assistem o parto de baixo risco e a mulher que vivencia o processo de parturição. A partir de observação participante das situações ocorridas no centro obstétrico de duas instituições e de entrevistas com puérperas, constatou-se que, entre profissionais e parturientes, prevalece a comunicação não terapêutica, imprimindo à assistência obstétrica um perfil de impessoalidade e exercício de poder do profissional sobre a mulher.

23. CARRARO, Telma Elisa; KNOBEL, Roxana; RADÜNZ, Vera; MEINCKE, Sonia Maria Könzgen; FIEWSKI, Marlei Fátima Cezarotto; FRELLO, Ariane Thaise; MARTINS, Marisa da Silva; LOPES, Caroline Vasconcellos; BERTON, Andressa. Cuidado e conforto durante o trabalho de parto e parto: na busca pela opinião das mulheres. Texto \& Contexto - Enfermagem, v.15, n. spe., p.97-104. 2006. Disponível em: <http://www.scielo.br/scielo. php?script=sci_arttext\&pid=S0104-07072006000500011\&lng=pt\&nrm=iso\&tlng=pt>. Acesso em: 25 ago. 2017.

- O artigo foi produzido a partir de uma pesquisa quali-quantitativa, descritiva prospectiva, que avaliou a opinião das mulheres puérperas sobre os métodos utilizados para seu cuidado e conforto durante o trabalho de parto e parto. O trabalho é um recorte dos dados qualitativos, focando nos sentimentos das mulheres puérperas durante essa vivência.

24. CARVALHO, Francisca Ana Martins; ORIÁ, Mônica Oliveira Batista; PINHEIRO, Ana Karina Bezerra; XIMENES, Lorena Barbosa. Significado do trabalho de parto: a perspectiva dos acadêmicos de enfermagem. Acta Paulista de Enfermagem, v.22, n.6, p.767-772. 2009. Disponível em: <http://www.scielo.br/scielo.php?script=sci_ arttext\&pid=S0103-21002009000600007\&lng=pt\&nrm=iso\&tlng=pt>. Acesso em: 10 set. 2017. 
- Analisa o significado do trabalho de parto para o aluno de enfermagem que participou da disciplina Enfermagem no processo de cuidar III - Saúde da mulher. Estudo de abordagem qualitativa, tendo como referencial teórico o interacionismo simbólico. Para a coleta de dados, foram usadas a observação participante e a entrevista aberta com vinte estudantes.

25. CARVALHO, Maria Luiza Mello de. Participação dos pais no nascimento em maternidade pública: dificuldades institucionais e motivações dos casais. Cadernos de Saúde Pública, v.19, supl.2, p.s389-s398. 2003. Disponível em: $<$ http://www.scielo.br/scielo.php?script=sci_arttext\&pid=S0102-311X2003000800020\&lng=pt\&nrm=is o\&tlng=pt $>$. Acesso em: 5 set. 2017.

- Analisa o impacto da participação dos pais no nascimento em uma maternidade pública, no Rio de Janeiro. Pesquisa etnográfica em duas etapas: observação-participante do trabalho de parto e do parto, e 11 entrevistas com pais participantes do parto. O estudo indica a necessidade de incentivo à participação dos pais no pré-natal, parto, pós-parto e nas consultas pediátricas; a preparação das equipes para trabalho com as famílias; a ampliação da discussão social sobre paternidade; e a formulação de políticas trabalhistas que garantam a presença dos pais nos serviços de saúde.

26. CARVALHO, Vanessa Franco de; KERBER, Nalú Pereira da Costa; BUSANELLO, Josefine; GONÇALVES, Bruna Goulart; RODRIGUES, Eloisa da Fonseca. Como os trabalhadores de um centro obstétrico justificam a utilização de práticas prejudiciais ao parto normal. Revista da Escola de Enfermagem da USP, v.46, n.1, p.30-37. 2012. Disponível em: <http://www.scielo.br/scielo.php?script=sci_arttext\&pid=\$0080-62342012000100004\&lng $=$ pt\&nrm=iso\&tlng=pt $>$. Acesso em: 13 set. 2017.

- Analisa as justificativas dos trabalhadores de um centro obstétrico do Sul do Brasil para a utilização de práticas do parto normal consideradas prejudiciais pela Organização Mundial da Saúde. Pesquisa exploratória, realizada em 2009, por meio de entrevistas. Conclui-se que algumas práticas prejudiciais ao parto continuam sendo desenvolvidas no atendimento às parturientes, sendo que as principais justificativas são a facilitação para a assistência no momento do parto e o autoritarismo que alguns trabalhadores têm em relação à parturiente, por acreditarem serem os únicos detentores de conhecimento.

27. CASTRILLO, Belén. Diga-me por quem é definido e vou dizer se é violento: uma reflexão sobre a violência obstétrica. Sexualidad, Salud y Sociedad (Rio de Janeiro), n.24, p.43-68. 2016. Disponível em: <http://www. scielo.br/scielo.php?script=sci_arttext\&pid=S1984-64872016000300043\&lng=pt\&nrm=iso\&tlng=es $>$. Acesso em: 15 set. 2017.

- Discute a definição de violência obstétrica em relação a certas relações e práticas na assistência médica à gravidez e ao parto. Aborda essa violência por meio de um modelo de análise socioantropológica e pela comparação entre definições objetivas (jurídicas, políticas, acadêmicas) e subjetivas produzidas por associações da sociedade civil. Assume que o que subjaz aos discursos sobre a violência obstétrica é uma disputa acerca da legitimidade de sua definição e que, nesse processo, a nomeação objetiva e os significados subjetivos atribuídos a certas práticas obstétricas como violentas se entrelaçam.

28. CASTRO, Cláudia Medeiros de. Os sentidos do parto domiciliar planejado para mulheres do município de São Paulo, São Paulo. Cadernos Saúde Coletiva, v.23, n.1, p.69-75. 2015. Disponível em: <http://www.scielo. $\mathrm{br} / \mathrm{scielo}$.php?script=sci_arttext\&pid=\$1414-462X2015000100069\&lng=pt\&nrm=iso\&tlng=pt $>$. Acesso em: 15 set. 2017.

- Analisa os sentidos da escolha do parto domiciliar a partir de uma pesquisa qualitativa com vinte mulheres que tiveram parto domiciliar planejado. Conclui pela necessidade de o Ministério da Saúde compor o cenário de discussão sobre o parto domiciliar planejado e que o direito de escolha do local de parto seja respeitado e garantido como parte dos direitos reprodutivos das mulheres e incluído nas ações do Serviço Único de Saúde. 
29. CASTRO, Jamile Claro de; CLAPIS, Maria José. Parto humanizado na percepção das enfermeiras obstétricas envolvidas com a assistência ao parto. Revista Latino-Americana de Enfermagem, v.13, n.6, p.960-967. 2005. Disponível em: <http://www.scielo.br/scielo.php?script=sci_arttext\&pid=S0104-11692005000600007\&lng =pt\&nrm=iso\&tlng=pt>. Acesso em: 22 ago. 2017.

- A partir de abordagem qualitativa, o estudo objetivou identificar a percepção das enfermeiras obstétricas sobre humanização da assistência ao parto, bem como evidenciar, por meio dos discursos, as ações desenvolvidas no processo de nascimento e os fatores dificultadores da implementação dessa assistência. As enfermeiras entrevistadas relataram que o processo de humanização se deu como uma estratégia política que objetiva a melhoria da assistência e o resgate do parto mais natural possível e que acreditam na necessidade de mudança de paradigma para que o processo se concretize. Os resultados evidenciaram, ainda, que as enfermeiras se apresentam mais integradas ao parto como um processo, e não como um evento.

30. CAUS, Eliz Cristine Maurer; SANTOS, Evanguelia Kotzias Atherino dos; NASSIF, Anair Andréia; MONTICELLI, Marisa. O processo de parir assistido pela enfermeira obstétrica no contexto hospitalar: significados para as parturientes. Escola Anna Nery, v.16, n.1, p.34-40. 2012. Disponível em: <http://www.scielo.br/scielo. php?script=sci_arttext\&pid=S1414-81452012000100005\&lng=pt\&nrm=iso\&tlng=pt>. Acesso em: 13 set. 2017. - Analisa o significado que a parturiente atribui ao processo de parir assistido pela enfermeira, à luz da teoria humanística, e identifica as contribuições desse processo para promover o cuidado humanístico. Os dados foram coletados em uma maternidade pública de Santa Catarina, com nove parturientes. Conclui-se que a parturiente assistida pela enfermeira obstétrica percebe um canal intersubjetivo aberto para o encontro, proporcionando-lhe mecanismos de chamadosrespostas indispensáveis ao cuidado de si e do recém-nascido.

31. CECAGNO, Susana; ALMEIDA, Francisca Dias de Oliveira de. Parto domiciliar assistido por parteiras em meados do século XX numa ótica cultural. Texto \& Contexto - Enfermagem, v.13, n.3, p.409-413. 2004. Disponível em: <http://www.scielo.br/scielo.php?script=sci_arttext\&pid=S0104-07072004000300010\&lng $=p t \& n r m=i s o \& t \operatorname{lng}=p t>$. Acesso em: 6 set. 2017.

- Investiga a experiência do processo de nascimento no domicílio assistido por parteiras, em meados do século passado. Estudo de caráter qualitativo, descritivo e exploratório, tendo como sujeitos seis mulheres na faixa etária de 70 a 90 anos, que tiveram seus filhos nos seus domicílios, auxiliadas por parteiras. A coleta de dados foi realizada por meio de um questionário aberto, cujas entrevistas foram gravadas, sendo os dados analisados posteriormente. Percebeu-se que o processo de parturição engloba aspectos além dos fisiológicos, envolvendo os valores culturais da mulher, da família e da comunidade.

32. CECHIN, Petronila Libana. Reflexões sobre o resgate do parto natural na era da tecnologia. Revista Brasileira de Enfermagem, v.55, n.4, p.444-448. 2002. Disponível em: <http://www.scielo.br/pdf/reben/v55n4/v55n4a15. pdf>. Acesso em: 21 ago. 2017.

- Tece algumas considerações reflexivas sobre o resgate do parto natural, apesar dos avanços tecnológicos na área obstétrica. Destaca a importância de se retomar as nossas raízes culturais para humanizar o processo da gestação e do parto. Argumenta que a interferência da tecnologia médica sobre o parto está associada ao poder econômico que se apossou do corpo, preconizando que o nascimento seguro é aquele que ocorre no meio hospitalar, munido de alta tecnologia e atitudes técnicas, muitas vezes desnecessárias.

33. CESAR, Juraci A.; MANO, Patrícia S.; CARLOTTO, Kharen; GONZALEZ-CHICA, David A.; MENDOZA-SASSI, Raul A. Público versus privado: avaliando a assistência à gestação e ao parto no extremo sul do Brasil. Revista Brasileira de Saúde Materno Infantil, v.11, n.3, p.257-263. 2011. Disponível em: <http://www.scielo.br/scielo.php?script=sci_ arttext\&pid=S1519-38292011000300006\&lng=pt\&nrm=iso\&tlng=pt>. Acesso em: 12 set. 2017.

- Avalia a assistência à gestação e ao parto no setor público e privado no município de Rio Grande (RS). Investiga aspectos relativos a cuidados recebidos desde o início da gestação até o pós- 
parto imediato. Conclui que gestantes do setor privado receberam de forma sistemática melhor assistência durante o pré-natal em termos de consultas e exames realizados, tiveram seu parto mais comumente realizado por médico, foram mais afetadas por intervenções desnecessárias como cesariana e episiotomia e menos frequentemente suplementadas com ferro.

34. CHIAVEGATTO FILHO, Alexandre Dias Porto. Partos cesáreos e a escolha da data de nascimento no município de São Paulo. Ciência \& Saúde Coletiva, v.18, n.8, p.2.413-2.420. 2013. Disponível em: <http://www.scielo.br/scielo. php?script=sci_arttext\&pid=S1413-81232013000800026\&lng=pt\&nrm=iso\&tlng=pt >. Acesso em: 14 set. 2013. - Analisa possíveis mudanças na data de nascimento decorrentes do aumento das taxas de parto cesáreo no Brasil. Foram obtidos os dados dos 1.933.137 nascidos vivos ocorridos no município de São Paulo entre 2001 e 2010, divididos segundo tipo de parto e data exata de nascimento. Em 2001, a taxa de cesarianas foi de 48,9\%, passando a 56,8\% em 2010. Mostra que o aumento no número de partos cesáreos tem tido efeito significativo na data de nascimento, o que pode trazer consequências no planejamento administrativo de instituições de saúde.

35. COLLAÇO, Vania Sorgatto; SANTOS, Evanguelia Kotzias Atherino dos; SOUZA, Kleyde Ventura de; ALVES, Herdy Valdecyr; ZAMPIERI, Maria de Fátima; GREGÓRIO, Vitória Regina Petters. O significado atribuído pelo casal ao parto domiciliar planejado, assistido pelas enfermeiras obstétricas da equipe Hanami. Texto \& Contexto Enfermagem, v.26, n.2, elocation e6030015. 2017. Disponível em: <http://www.scielo.br/scielo.php?script=sci_ arttext\&pid=S0104-07072017000200303\&lng=pt\&nrm=iso\&tlng=pt>. Acesso em: 16 set. 2017.

- Analisa o significado atribuído pelo casal sobre a experiência do parto domiciliar planejado, assistido pelas enfermeiras obstétricas da equipe Hanami. Estudo de natureza qualitativa, na modalidade de pesquisa convergente-assistencial, desenvolvida com trinta casais, no Sul do Brasil, no período de outubro de 2011 a novembro de 2012. Concluiu que o contexto ambiental do domicílio interfere na totalidade de uma experiência singular que respeita as dimensões físicas, holístico-ecológicas, emocionais e culturais do casal, trazendo à tona o domicílio como o local de escolha para a ocorrência do parto.

36. COSTA, Nilma Dias Leão; PAES, Neir Antunes; RAMOS, Paulo César Formiga; FORMIGA, Maria Célia de Carvalho. Desejo, intenção e comportamento na saúde reprodutiva: a prática da cesárea em cidade do Nordeste do Brasil. Revista Brasileira de Ginecologia e Obstetrícia, v.28, n.7, p.388-396. 2006. Disponível em: $<$ http://www.scielo.br/scielo.php?script=sci_arttext\&pid=\$0100-72032006000700003\&lng=pt\&nrm=iso\&tl $\mathrm{ng}=\mathrm{pt}>$. Acesso em: 7 set. 2017.

- Investiga os fatores determinantes da alta incidência do parto cesáreo e a sua inter-relação com a esterilização. A pesquisa é parte de estudo multicêntrico sobre saúde reprodutiva no Brasil, realizado de 1998 a 2000, que incluiu os estados do Rio Grande do Norte, Minas Gerais, São Paulo e Rio Grande do Sul. Caracterizou-se como longitudinal prospectivo, no qual foram entrevistadas mulheres, provenientes do serviço público e do privado. Mostra as grandes diferenças existentes entre o setor público e o privado, com um claro favorecimento ao privado; e que as mulheres com acesso ao serviço privado conseguem a realização da cesárea sem consistentes indicações médicas e que as mulheres com acesso ao serviço público enfrentam dificuldades para realização desse procedimento, mesmo com procedentes indicações médicas.

37. DAVIM, Rejane Marie Barbosa; BEZERRA, Luiz Gonzaga de Medeiros. Assistência à parturiente por enfermeiras obstétricas no Projeto Midwifery: um relato de experiência. Revista Latino-Americana de Enfermagem, v.10, n.5, p.727-732. 2002. Disponível em: <http://www.scielo.br/scielo.php?script=sci_arttext\&pid=S0104$11692002000500016 \&$ Ing=pt\&nrm=iso\&tlng=pt $>$. Acesso em: 4 set. 2017.

- Destaca os modelos assistenciais de enfermagem que valorizam a mulher no processo do trabalho de parto, parto e nascimento. Ressalta que a prática desses modelos possibilita a participação ativa do enfermeiro no processo de trabalho de parto, parto e nascimento, proporcionando, fundamentalmente, satisfação à parturiente e ao profissional. 
38. DAVIM, Rejane Marie Barbosa; MENEZES, Rejane Maria Paiva de. Assistência ao parto normal no domicílio. Revista Latino-Americana de Enfermagem, v.9, n.6, p.62-68. 2001. Disponível em: <http://www.scielo.br/scielo. php?script=sci_arttext\&pid=S0104-11692001000600011\&lng=pt\&nrm=iso\&tlng=pt>. Acesso em: 17 set. 2017. - Trata da experiência vivenciada por uma enfermeira obstetra com um casal grávido de seu terceiro filho. Destaca os modelos assistenciais que valorizam a mulher e o casal no processo do nascimento e parto. Descreve a assistência prestada a um casal durante o processo da gestação e parto realizado no domicílio. Ressalta que a experiência possibilitou a participação ativa do casal e filhos no processo do nascimento e parto, propiciando, fundamentalmente, satisfação à família e ao profissional.

39. DESLANDES, Suely Ferreira. A ótica de gestores sobre a humanização da assistência nas maternidades municipais do Rio de Janeiro. Ciência \& Saúde Coletiva, v.10, n.3, p.615-626. 2005. Disponível em: <http:// www.scielo.br/scielo.php?script=sci_arttext\&pid=S1413-81232005000300018\&lng=pt\&nrm=iso\&tlng= pt>. Acesso em: 23 ago. 2017.

- Estudo exploratório e hermenêutico da ótica de gestores sobre a trajetória de implantação e a identidade das iniciativas de humanização da assistência adotadas pela Secretaria de Saúde do Município do Rio de Janeiro. A partir da metodologia de análise das narrativas e das concepções de gestores e macrogestores, são analisadas e confrontadas as trajetórias de instituição da política de humanização ao parto e de atenção ao recém-nascido de baixo peso.

40. DIAS, Marcos Augusto Bastos; DESLANDES, Suely Ferreira. Cesarianas: percepção de risco e sua indicação pelo obstetra em uma maternidade pública no Município do Rio de Janeiro. Cadernos de Saúde Pública, v.20, n.1, p.109-116. 2004. Disponível em: <http://www.scielo.br/scielo.php?script=sci_arttext\&pid=S0102-311X2 $004000100025 \& \operatorname{lng}=$ pt\&nrm=iso\&tlng=pt>. Acesso em: 6 set. 2017.

- Analisa as representações de médicos sobre os riscos inerentes da cesariana que influenciam a sua indicação. Neste estudo qualitativo, realizado com observação participante de plantões e entrevistas com obstetras, identificou-se que as indicações feitas pelos obstetras da unidade pública estudada sofrem influência de diversos fatores não obstétricos: a insegurança quanto às manobras obstétricas, a fragmentação do atendimento e o medo da responsabilização jurídica, entre outros.

41. DIAS, Marcos Augusto Bastos; DESLANDES, Suely Ferreira. Expectativas sobre a assistência ao parto de mulheres usuárias de uma maternidade pública do Rio de Janeiro, Brasil: os desafios de uma política pública de humanização da assistência. Cadernos de Saúde Pública, v. 22, n.12, p.2.647-2.655. 2006. Disponível em: $<$ http://www.scielo.br/scielo.php?script=sci_arttext\&pid=S0102-311X2006001200014\&lng=pt\&nrm=iso\&tl $\mathrm{ng}=\mathrm{pt}>$. Acesso em: 23 ago. 2017.

- Analisa as expectativas de gestantes, usuárias de uma maternidade pública no município do Rio de Janeiro, sobre a assistência que receberam no parto e a avaliação que fazem do atendimento recebido em partos anteriores. Foram analisadas informações das mulheres sobre humanização da assistência ao parto, experiências relativas à assistência recebida em parto(s) anterior(es), seu ideal de atendimento ao parto eminente e sobre a atenção da equipe de saúde.

42. DIAS, Marcos Augusto Bastos; DOMINGUES, Rosa Maria Soares Madeira. Desafios na implantação de uma política de humanização da assistência hospitalar ao parto. Ciência \& Saúde Coletiva, v.10, n.3, p.699-705.2005. Disponível em: <http://www.scielo.br/scielo.php?script=sci_arttext\&pid=S1413-81232005000300026\&lng $=p t \& n r m=i s o \& t \operatorname{lng}=p t>$. Acesso em: 23 ago. 2017.

- Discute as dificuldades de implantação de um novo modelo de assistência ao parto de baixo risco na estrutura hospitalar e na sistematização de um campo de trabalho da enfermeira obstetra. Sob uma nova perspectiva do cuidado da parturiente, os autores fazem uma reflexão sobre o modelo de atuação dessa categoria profissional, dos possíveis resultados positivos decorrentes dessa nova assistência e do conflito gerado pela divisão de um espaço até então de domínio exclusivo da categoria médica e do consequente choque de modelos de cuidados. 
43. DIAS, Marcos Augusto Bastos; DOMINGUES, Rosa Maria Soares Madeira; PEREIRA, Ana Paula Esteves; FONSECA, Sandra Costa; GAMA, Silvana Granado Nogueira da; THEME FILHA, Mariza Miranda; BITTENCOURT, Sonia Duarte Azevedo; ROCHA, Penha Maria Mendes da; SCHILITHZ, Arthur Orlando Correa; LEAL, Maria do Carmo. Trajetória das mulheres na definição pelo parto cesáreo: estudo de caso em duas unidades do sistema de saúde suplementar do estado do Rio de Janeiro. Ciência \& Saúde Coletiva, v.13, n.5, p.1.521-1.534. 2008. Disponível em: <http://www.scielo.br/scielo.php?script=sci_arttext\&pid=S1413-81232008000500017\&lng $=p t \& n r m=i s o \& t \operatorname{lng}=p t>$. Acesso em: 8 set. 2017.

- Descreve as características socioeconômicas, demográficas, culturais e reprodutivas de puérperas e os determinantes da decisão por parto cesáreo em duas unidades do sistema de saúde suplementar do estado do Rio de Janeiro. Observou-se que, embora 70\% das entrevistadas não relatassem preferência inicial pela cesariana, 90\% apresentaram esse tipo de parto. Verificou-se que, independente do desejo inicial da gestante, a interação com o serviço de saúde resultou na cesariana como via final de parto.

44. DINIZ, Carmen Simone Grilo. Humanização da assistência ao parto no Brasil: os muitos sentidos de um movimento. Ciência \& Saúde Coletiva, v.10, n.3, p.627-637. 2005. Disponível em: <http://www.scielo.br/scielo. php?script=sci_arttext\&pid=S1413-81232005000300019\&lng=pt\&nrm=iso\&tlng=pt>. Acesso em: 23 ago. 2017.

- Recupera as origens do termo humanização do parto, o reconhecimento da assistência ao parto como evento desumanizante, a crítica técnica à assistência, o surgimento de um movimento nacional e internacional de humanização do parto, as políticas de humanização do parto desenvolvidas no Brasil, e as relações entre a crítica à assistência e a criação do movimento pela medicina baseada em evidências. Com base em um estudo de duas maternidades "humanizadas" do SUS, discute os diferentes (às vezes contraditórios) sentidos do termo, e seu alcance em questionar a cultura técnico-assistencial, a anatomia, a fisiologia feminina e as relações de gênero

45. DINIZ, Carmen Simone; BATISTA, Luís Eduardo; KALCKMANN, Suzana; SCHLITHZ, Arthur; QUEIROZ, Marcel; CARVALHO, Priscila. Desigualdades sociodemográficas e na assistência à maternidade entre puérperas no Sudeste do Brasil segundo cor da pele: dados do inquérito nacional Nascer no Brasil (2011-2012). Saúde e Sociedade, v.25, n.3, p.561-572. 2016. Disponível em: <http://www.scielo.br/scielo.php?script=sci_ arttext\&pid=S0104-12902016000300561\&lng=pt\&nrm=iso\&tlng=pt>. Acesso em: 15 set. 2017.

- Analisa as mudanças nas desigualdades sociodemográficas e na assistência à maternidade no Sudeste do Brasil, segundo raça/cor, na última década. Encontraram-se diferenças desfavoráveis às pretas e pardas quanto à escolaridade, renda e ao trabalho remunerado; as brancas tinham mais planos de saúde privados e maior idade. As pretas e pardas tiveram menor número de consultas, menos ultrassonografias, mais cuidado pré-natal considerado inadequado, maior paridade e mais síndromes hipertensivas.

46. DOMINGUES, Rosa Maria Soares Madeira; SANTOS, Elizabeth Moreira dos; LEAL, Maria do Carmo. Aspectos da satisfação das mulheres com a assistência ao parto: contribuição para o debate. Cadernos de Saúde Pública, v.20, supl.1, p.S52-S62. 2004. Disponível em: <http://www.scielo.br/scielo.php?script=sci_ arttext\&pid=S0102-311X2004000700006\&lng=pt\&nrm=iso\&tlng=pt>. Acesso em: 6 set. 2017.

- Analisa os fatores que estiveram associados à satisfação das mulheres com a assistência ao parto normal na Maternidade Leila Diniz. Estudo com desenho transversal por meio de entrevista com puérperas de parto vaginal internadas no período de $1^{\circ}$ a 30 de março de 1999 . Encontrouse uma elevada satisfação com o parto $(67 \%)$, sendo os principais determinantes da satisfação a rapidez do parto, o bom tratamento da equipe, o pouco sofrimento, o bom estado da mãe e do bebê, bem como a presença do acompanhante familiar.

47. D'ORSI, Eleonora; CHOR, Dóra; GIFFIN, Karen; ANGULO-TUESTA, Antonia; BARBOSA, Gisele Peixoto; GAMA, Andrea de Souza; REIS, Ana Cristina; HARTZ, Zulmira. Qualidade da atenção ao parto em maternidades do 
Rio de Janeiro. Revista de Saúde Pública, v.39, n.4, p.645-654. 2005. Disponível em: <http://www.scielo.br/ scielo.php?script=sci_arttext\&pid=S0034-89102005000400020\&lng=pt\&nrm=iso\&tlng=pt>. Acesso em: 6 set. 2017.

- Avalia a qualidade da atenção durante o processo de trabalho de parto de acordo com normas da Organização Mundial de Saúde. Trata-se de estudo do tipo caso-controle, realizado em duas maternidades: pública e conveniada com o Sistema Único de Saúde, no município do Rio de Janeiro. As duas maternidades apresentam frequência elevada de intervenções durante a assistência ao parto. A maternidade pública, apesar de atender clientela com maior risco gestacional, apresenta perfil menos intervencionista que a maternidade conveniada.

48. FAISAL-CURY, Alexandre; MENEZES, Paulo Rossi. Fatores associados à preferência por cesariana. Revista de Saúde Pública, v.40, n.2, p.226-232. 2006. Disponível em: <http://www.scielo.br/scielo.php?script=sci_ arttext\&pid=S0034-89102006000200007\&lng=pt\&nrm=iso\&tlng=pt>. Acesso em: 7 set. 2017.

- Estuda os fatores relacionados à preferência por cesariana em gestantes sem intercorrências. Estudo transversal com 156 gestantes de clínica privada na cidade de Osasco (SP) no período de outubro de 2000 a dezembro de 2001. Foi aplicado questionário sobre informações sociodemográficas, história obstétrica passada e atual. Conclui que a motivação para parto cesariano está associada a influências como tipo e grau de satisfação com o parto prévio e renda.

49. FARIA, Renata Mercês Oliveira de; SAYD, Jane Dutra. Abordagem sócio-histórica sobre a evolução da assistência ao parto num município de médio porte de Minas Gerais (1960-2001).Ciência \& Saúde Coletiva, v.18, n.8, p.2.421-2430. 2013. Disponível em: <http://www.scielo.br/scielo.php?script=sci_arttext\&pid=S1413$81232013000800027 \&$ lng=pt\&nrm=iso\&tlng=pt>. Acesso em: 14 set. 2017.

- Caracteriza a evolução da série histórica quanto ao tipo de parto, normal, cesárea e fórceps, no período de 1960 a 2001, nas três maternidades mais antigas e conveniadas ao Sistema Único de Saúde de Juiz de Fora. Utiliza o método da história serial e identifica o aumento de incorporação tecnológica nesta trajetória e o crescente uso da cesariana até 1998. A partir de então, identifica-se o impacto da portaria n.2.816, proposta pelo Ministério da Saúde, para inversão dessa tendência. Conclui que o conhecimento das desigualdades e problematização de sua existência é precondição para obter o encaminhamento da solução.

50. FAÚNDES, Aníbal; PÁDUA, Karla Simônia de; OSIS, Maria José Duarte; CECATTI, José Guilherme; SOUSA, Maria Helena de. Opinião de mulheres e médicos brasileiros sobre a preferência pela via de parto. Revista de Saúde Pública, v.38, n.4, p.488-494. 2004. Disponível em: <http://www.scielo.br/scielo.php?script=sci_ arttext\&pid=S0034-89102004000400002\&lng=pt\&nrm=iso\&tlng=pt>. Acesso em: 5 set. 2017.

- Analisa a preferência de mulheres quanto às vias e formas de parto, e a opinião de médicos a respeito dessa preferência. Foram entrevistadas 656 mulheres atendidas no Sistema Único de Saúde, em hospitais de São Paulo e Pernambuco. Os médicos responderam a um autoquestionário, sendo 77 dos hospitais de intervenção e 70 dos de controle. Conclui que o conceito de que a principal causa do aumento na taxa de cesárea é o respeito dos desejos das mulheres por parte dos médicos não tem sustentação na opinião declarada pelas mulheres. Uma melhor comunicação entre médicos e mulheres grávidas talvez possa contribuir para melhoria da situação atual.

51. FERREIRA JUNIOR, Antonio Rodrigues; BARROS, Nelson Filice de. Motivos para atuação e formação profissional: percepção de doulas. Physis: Revista de Saúde Coletiva, v.26, n.4, p.1.395-1.407. 2016. Disponível em: <http://www.scielo.br/scielo.php?script=sci_arttext\&pid=S0103-73312016000401395\&lng=pt\&nrm=is o\&tlng=pt>. Acesso em: 16 set. 2017.

- Analisa os fatores motivacionais para mulheres buscarem a formação de doula e desenvolverem suas atividades profissionais. Pesquisa qualitativa exploratório-descritiva, realizada com 13 doulas, participantes de formação específica, através de entrevistas individuais por telefone. 
Evidenciou-se que experiências individuais com o próprio parto motivaram mulheres na busca dessa formação e que o fortalecimento da profissionalização por meio da constituição de grupos é uma forma buscada pelas doulas para qualificar sua atuação na obstetrícia.

52. FEYER, lara Simoni Silveira; MONTICELLI, Marisa; BOEHS, Astrid Eggert; SANTOS, Evanguelia Kotzias Atherino dos. Rituais de cuidado realizados pelas famílias na preparação para a vivência do parto domiciliar planejado. Revista Brasileira de Enfermagem, v.66, n.6, p.879-886. 2013. Disponível em: <http://www.scielo.br/scielo. php?script=sci_arttext\&pid=S0034-71672013000600011\&lng=pt\&nrm=iso\&tlng=pt $>$. Acesso em: 14 set. 2017.

- Analisa, por meio de pesquisa etnográfica, os rituais de cuidado realizados por famílias durante a preparação para a vivência de parto domiciliar planejado. Participaram 25 famílias, no período de setembro de 2010 a abril de 2011. As técnicas de coleta de dados foram a observação participante e a entrevista. Conclui que o parto domiciliar é uma experiência construída no âmbito do casal grávido. A casa é concebida pelas famílias como um local sagrado para a vivência de uma experiência que agregue valores existenciais ao ato fisiológico do nascimento. Compreender esses rituais contribui para o oferecimento de cuidado de enfermagem culturalmente congruente.

53. FEYER, lara Simoni Silveira; MONTICELLI, Marisa; VOLKMER, Cilene; BURIGO, Renata Angeloni. Publicações científicas brasileiras de enfermeiras obstétricas sobre parto domiciliar: revisão sistemática de literatura. Texto \& Contexto - Enfermagem, v.22, n.1, p.247-256.2013. Disponível em: $<$ http://www.scielo.br/scielo.php?script=sci_ arttext\&pid=S0104-07072013000100030\&lng=pt\&nrm=iso\&tlng=pt >. Acesso em: 14 set. 2017.

- Estudo de revisão, em periódicos nacionais, realizado com o objetivo de caracterizar a produção científica das enfermeiras brasileiras sobre o parto domiciliar e identificar os resultados alcançados. Dos 27 artigos localizados, dez atenderam aos critérios de inclusão e exclusão e oito constituíram o corpus analítico, segundo o Critical Appraisal Skills Programme. Os dados foram sintetizados pela abordagem metaetnográfica, seguindo a interpretação da reciprocal translation. Os resultados mostram a prática das parteiras tradicionais, a satisfação das mulheres que tiveram seus filhos em casa e revelam importante lacuna sobre a produção de conhecimentos da enfermeira obstétrica no parto domiciliar.

54. FIGUEIRÊDO, Nébia Maria Almeida de; TYRRELL, Maria Antonieta Rubio; CARVALHO, Vilma de; LEITE, Joséte Luzia. Indicadores de cuidados para o corpo que pro-cria: ações de enfermagem no pré-, trans- e pós-parto: uma contribuição para a prática de enfermagem obstétrica. Revista Latino-Americana de Enfermagem, v.12, n.6, p.905-912. 2004. Disponível em: <http://www.scielo.br/scielo.php?script=sci_arttext\&pid=S0104$11692004000600009 \&$ Ing=pt\&nrm=iso\&tlng=pt $>$. Acesso em: 5 set. 2017.

- O estudo é o resultado de dinâmicas entendidas como Cenas de Produção Estética feitas com 28 profissionais de ensino e de serviços de enfermagem para responder à questão: o que se produz sobre o corpo em trabalho de parto quando cuidamos dele no pré-, trans- e pós-parto? Identifica e discute as ações nestes momentos em que o corpo da mulher dá origem a outra vida. Três categorias surgiram como resultado: (1) O cuidado do corpo em trabalho de parto: a (in) devida invasão e a violência velada; (2) $\mathrm{O}$ (des)cuidado do corpo que (ex)pulsa outro corpo: a invasão e a violência mostrada; (3) O (des)cuidado do corpo vazio: "cansaço e solidão" "a violência do abandono". Essas categorias apontam que existem cuidados para essa clientela que devem evitar a violência sobre o corpo da mulher em processo de parto.

55. FLEISCHER, Soraya. Então, minha filha, vamos se afomentar? Puxação, parteiras e reprodução em Melgaço, Pará. Ciência \& Saúde Coletiva, v.13, n.3, p.889-898. 2008. Disponível em: <http://www.scielo.br/scielo. php?script=sci_arttext\&pid=S1413-81232008000300011\&lng=pt\&nrm=iso\&tlng=pt $>$. Acesso em: 8 set. 2017. - Apresenta dados etnográficos, coletados entre 2004 e 2005, relativos ao atendimento obstétrico oferecido por um grupo de 21 parteiras na cidade de Melgaço, estado do Pará, Brasil, e discute a prática da puxação, massagem abdominal realizada sobretudo em gestantes. A puxação tem 
como objetivo aliviar indisposições, informar a posição e o sexo do feto, a previsão da data e local do parto, socializar a mulher para a maternidade e contextualizar a gestação dentro dos padrões locais de reprodução, família, bem-estar e saúde. Conclui que essas parteiras oferecem um serviço pré-natal muito próprio e adequado às necessidades específicas das mulheres da cidade.

56. FRANK, Tatianne Cavalcanti; PELLOSO, Sandra Marisa. A percepção dos profissionais sobre a assistência ao parto domiciliar planejado. Revista Gaúcha de Enfermagem, v.34, n.1, p.22-29. 2013. Disponível em: <http:// www.scielo.br/scielo.php?script=sci_arttext\&pid=S1983-14472013000100003\&lng=pt\&nrm=iso\&tlng= pt>. Acesso em: 14 set. 2013.

- Analisa a percepção dos profissionais no acompanhamento do parto domiciliar planejado. Foram entrevistados oito profissionais que atuaram em partos domiciliares em Cascavel (PR). A análise revelou que o domicílio, enquanto local de assistência, possibilita o protagonismo da mulher e da família pela tranquilidade, calma e autonomia. O ambiente é seguro quando se seguem requisitos como baixo risco gestacional, avaliação adequada no decorrer da evolução do parto, presença de materiais adequados, rede transdisciplinar e local predefinido para encaminhamentos. Os profissionais apontam, ainda, como fundamental a participação familiar no processo. Conclui-se que o parto domiciliar é uma excelente estratégia para transformar e melhorar a qualidade da atenção obstétrica.

57. FREITAS, Paulo Fontoura; MOREIRA, Bianca Carvalho; MANOEL, Andre Luciano; BOTURA, Ana Clara de Albuquerque. O parecer do Conselho Federal de Medicina, o incentivo à remuneração ao parto e as taxas de cesariana no Brasil. Cadernos de Saúde Pública, v.31, n.9, p.1.839-1.855. 2015. Disponível em: <http://www. scielo.br/scielo.php?script=sci_arttext\&pid=S0102-311X2015000901839\&lng=pt\&nrm=iso\&tlng=pt >. Acesso em: 15 set. 2017.

- Investiga como o incentivo à remuneração ao parto, preconizado pelo Conselho Federal de Medicina (CFM) do Brasil, influencia as taxas de cesariana. Foi investigada uma amostra consecutiva de seiscentas puérperas. Postula que o entendimento do CFM de que o incentivo ao acompanhamento presencial do trabalho de parto, pago à parte, para o mesmo obstetra que realizou o pré-natal, funcionará como incentivo ao parto normal, está na contramão dos resultados do estudo, mostrando que as mulheres atendidas pelo mesmo profissional no prénatal e parto são exatamente aquelas que apresentam as taxas de cesariana mais elevadas.

58. GAMA, Andréa de Sousa; GIFFIN, Karen Mary; ANGULO-TUESTA, Antonia; BARBOSA, Gisele Peixoto; D'ORSI, Eleonora. Representações e experiências das mulheres sobre a assistência ao parto vaginal e cesárea em maternidades pública e privada. Cadernos de Saúde Pública, v.25, n.11, p.2.480-2.488. 2009. Disponível em: $<$ http://www.scielo.br/scielo.php?script=sci_arttext\&pid=S0102-311X2009001100017\&lng=pt\&nrm=iso\&tl $\mathrm{ng}=\mathrm{pt}>$. Acesso em: 29 ago. 2017.

- Analisa as diferentes representações e experiências quanto ao parto vaginal e cesárea de mulheres de diferentes estratos socioeconômicos, bem como a natureza das relações profissionais de saúde/usuárias no contexto institucional em que estão inseridas. Os resultados revelam que o modelo de organização dos serviços público e privado apresentam variações que produzem diferentes tipos de assistência e de relação entre os profissionais de saúde e as usuárias, dando forma a experiências distintas entre as mulheres pesquisadas.

59. GIFFIN, Karen. Pobreza, desigualdade e equidade em saúde: considerações a partir de uma perspectiva de gênero transversal. Cadernos de Saúde Pública, v.18, supl., p.S103-S112. 2002. Disponível em: <http://www. scielo.br/scielo.php?script=sci_arttext\&pid=S0102-311X2002000700011\&lng=pt\&nrm=iso\&tlng=pt $>$. Acesso em: 4 set. 2017.

- Aborda a atualização das desigualdades de gênero que ocorrem no Brasil nas últimas duas décadas, sob a hegemonia das políticas macroeconômicas de cunho neoliberal. No centro desta análise, um conceito de gênero transversal é aplicado a questões da saúde reprodutiva 
(contracepção e aborto, parto e pré-natal, gravidez na adolescência, mortalidade materna e reprodutiva, DST/Aids e violência, entre outras) permitindo relacionar os gêneros e comparar mulheres de diferentes classes sociais. De forma diversa, a história do Programa de Assistência Integral à Saúde da Mulher revela a complexa articulação entre uma política pública nacional fortemente influenciada pelo movimento de mulheres, mas permeável a interesses heterogêneos no contexto internacional.

60. GOMES, Maysa Luduvice; MOURA, Maria Aparecida Vasconcelos; SOUZA, Ivis Emília de Oliveira. A prática obstétrica da enfermeira no parto institucionalizado: uma possibilidade de conhecimento emancipatório. Texto \& Contexto - Enfermagem, v.22, n.3, p.763-771. 2013. Disponível em: <http://www.scielo.br/scielo. php?script=sci_arttext\&pid=S0104-07072013000300024\&lng=pt\&nrm=iso\&tlng=pt $>$. Acesso em: 14 set. 2017.

- Analisa os sentidos atribuídos pelas enfermeiras às mudanças de sua prática obstétrica, utilizando o método produção de sentidos no cotidiano/práticas discursivas, proposto por Mary Spink. Dados coletados por entrevista individual, semiestruturada, com 16 enfermeiras obstétricas em maternidades públicas no Rio de Janeiro, Brasil. Os sentidos atribuídos pelas enfermeiras às práticas obstétricas evidenciaram uma transformação em processo no âmbito do conhecimento obstétrico e das práticas na perspectiva da desmedicalização.

61. GONÇALVES, Roselane; AGUIAR, Cláudia de Azevedo; MERIGHI, Miriam Aparecida Barbosa; JESUS, Maria Cristina Pinto de. Vivenciando o cuidado no contexto de uma casa de parto: o olhar das usuárias. Revista da Escola de Enfermagem da USP, v.45, n.1, p.62-70. 2011. Disponivel em: <http://www.scielo.br/scielo. php?script=sci_arttext\&pid=\$0080-62342011000100009\&lng=pt\&nrm=iso\&tlng=pt $>$. Acesso em: 31 ago. 2017.

- Discute a compreensão da vivência da mulher parturiente em uma casa de parto situada em São Paulo. Os dados foram coletados em 2007 e analisados sob o referencial da fenomenologia social. Os resultados evidenciaram que a mulher que escolhe a casa de parto para dar à luz busca o cuidado humanizado e que nesse contexto ela passa por experiências positivas e negativas.

62. GREGÓRIO, Vitoria Regina Petters; PADILHA, Maria Itayra Coelho de Souza. História do cuidado à mulher na Maternidade Carmela Dutra, Florianópolis-SC, Brasil (1956-2001). Revista Brasileira de Enfermagem, v.65, n.5, p.767-774. 2012. Disponível em: <http://www.scielo.br/scielo.php?script=sci_arttext\&pid=S0034$71672012000500008 \&$ Ing=pt\&nrm=iso\&tlng=pt>. Acesso em: 13 set. 2017.

- Analisa as práticas de cuidado desenvolvidas pelas enfermeiras com mulheres na Maternidade Carmela Dutra, de Florianópolis (SC). Pesquisa qualitativa com abordagem sócio-histórica. Foram entrevistadas nove enfermeiras, utilizando-se a técnica de história oral temática. Concluiu-se que o cuidado prestado à mulher na maternidade foi exercido por religiosas e parteiras, por enfermeiras leigas e por enfermeiras obstétricas, numa trajetória que vai do cuidado laico ao profissional, entrelaçado por relações de saber-poder demarcadas por lutas e resistências ao poder médico hegemônico da época.

63. GRIBOSKI, Rejane Antonello; GUILHEM, Dirce. Mulheres e profissionais de saúde: o imaginário cultural na humanização ao parto e nascimento. Texto \& Contexto - Enfermagem, v.15, n.1, p.107-114. 2006. Disponível em: $<$ http://www.scielo.br/scielo.php?script=sci_arttext\&pid=S0104-07072006000100013\&/ng=pt\&nrm=is o\&tlng=pt>. Acesso em: 24 ago. 2017.

- Busca conhecer o impacto da política de humanização ao parto e nascimento, para mulheres e profissionais de saúde, por meio de pesquisa qualitativa, tomando como referencial metodológico a análise de conteúdo e os dados coletados em entrevistas individuais. Entre as mulheres foram encontrados sensação de medo e desconhecimento do processo parturitivo, e entre os profissionais foi identificada uma hierarquização nas relações entre eles e as mulheres. Ficou evidente a falta de comunicação na assistência dispensada por eles às mulheres. 
64. HADDAD, Samira El Maerrawi T.; CECATTI, José Guilherme. Estratégias dirigidas aos profissionais para a redução das cesáreas desnecessárias no Brasil. Revista Brasileira de Ginecologia e Obstetrícia, v.33, n.5, p.252-262. 2011. Disponível em: <http://www.scielo.br/scielo.php?script=sci_arttext\&pid=S0100$72032011000500008 \&$ lng=pt\&nrm=iso\&tlng=pt>. Acesso em: 12 set. 2017.

- Apresenta o problema do excesso de cesarianas no Brasil e os diversos efeitos prejudiciais da realização não criteriosa de parto cesárea. Afirma que nenhum fator isoladamente é capaz de justificar a complexidade da decisão pelo parto por cesárea, mas que o médico e o tipo de hospital são os maiores fatores associados. Os diversos efeitos prejudiciais da realização não criteriosa de parto cesárea são cientificamente comprovados. Postula que é fundamental a conscientização de médicos e demais profissionais sobre as consequências reais da utilização inadequada da cesárea; os desvios éticos quando condutas são tomadas sem que o foco seja exclusivamente a saúde do paciente; e a necessidade de capacitação e atualização constantes para o manejo das diversas situações possíveis para o nascimento.

65. HOGA, Luiza Akiko Komura. Casa de parto: simbologia e princípios assistenciais. Revista Brasileira de Enfermagem, v.57, n.5, p.537-540. 2004. Disponível em: <http://www.scielo.br/scielo.php?script=sci_ arttext\&pid=S0034-71672004000500004\&lng=pt\&nrm=iso\&tlng=pt>. Acesso em: 22 ago. 2017.

- Identifica os símbolos que permeiam as ideias, crenças, valores e práticas e os princípios que orientam a assistência prestada na primeira casa de parto vinculada ao Programa Saúde da Família. O método de pesquisa foi a etnografia, e a história oral temática foi o recurso empregado para entrevistar enfermeiras obstétricas da casa.

66. HOTIMSKY, Sonia Nussenzweig; ALVARENGA, Augusta Thereza de. A definição do acompanhante no parto: uma questão ideológica? Revista Estudos Feministas, v.10, n.2, p.461-481. 2002. Disponível em: <http://www. scielo.br/scielo.php?script=sci_arttext\&pid=S0104-026X2002000200015\&lng=pt\&nrm=iso\&tlng=pt>. Acesso em: 22 ago. 2017.

- Descreve padrões de acompanhamento na cena do parto em um serviço de saúde "alternativo" com uma proposta de parto ambulatorial realizado fora do hospital, assistido por obstetrizes, discutindo sua relação com as diferentes formas de sociabilidade, inclusive de relações de gênero, existentes entre as mulheres e os homens de distintas origens sociais que frequentavam esse serviço. Por fim, discute os limites impostos, sobretudo pela legislação estadual de São Paulo e pelo Estatuto da Criança e do Adolescente, ao leque de "opções" de acompanhante(s) elegidas pelas parturientes e aos membros de suas redes de relações.

67. HOTIMSKY, Sonia Nussenzweig; RATTNER, Daphne; VENANCIO, Sonia Isoyama; BÓGUS, Cláudia Maria; MIRANDA, Marinês Martins. O parto como eu vejo... ou como eu o desejo? Expectativas de gestantes, usuárias do SUS, acerca do parto e da assistência obstétrica. Cadernos de Saúde Pública, v.18, n.5, p.1.3031.311. 2002. Disponível em: <http://www.scielo.br/scielo.php?script=sci_arttext\&pid=S0102-311X2002000 500023\&lng=pt\&nrm=iso\&tlng=pt>. Acesso em: 21 ago. 2017.

- Propõe-se a identificar as expectativas de gestantes em relação ao tipo de parto. Por meio de grupos focais em um hospital público na cidade de São Paulo, evidenciou-se deficiência de informações sobre questões da vida reprodutiva, todavia, a preferência era pelo parto vaginal, sendo a cesárea temida pelos riscos a ela associados. As autoras propõem revisão da demanda das mulheres por cesárea como um dos fatores para a escalada de cesarianas no país.

68. HOTIMSKY, Sonia Nussenzweig; SCHRAIBER, Lilia Blima. Humanização no contexto da formação em obstetrícia. Ciência \& Saúde Coletiva, v.10, n.3, p.639-649. 2005. Disponível em: <http://www.scielo.br/scielo.php?script=sci_ arttext\&pid=S1413-81232005000300020\&lng=pt\&nrm=iso\&tlng=pt>. Acesso em: 23 ago. 2017.

- Propõe uma reflexão acerca do tema da humanização do parto no contexto da formação em obstetrícia. A partir de incursão etnográfica no acompanhamento de um curso oferecido pelo Departamento de Obstetrícia e Ginecologia de conceituada faculdade de medicina em 
São Paulo, e de visitas de seus alunos a serviços públicos de "assistência humanizada" reflete sobre as repercussões no ensino da atenção ao parto. Encontram que a noção de humanização contrapõe modelos de atenção apresentados nas visitas ao serviço existente no hospital-escola e, ainda, modelos ideais propostos por seus professores. As visitas e suas repercussões constituíram também uma oportunidade de consolidação de uma identidade coletiva em formação.

69. JAMAS, Milena Temer; HOGA, Luiza Akiko Komura; REBERTE, Luciana Magnoni. Narrativas de mulheres sobre a assistência recebida em um centro de parto normal. Cadernos de Saúde Pública, v.29, n.12, p.2.436-2.446. 2013. Disponivel em: <http://www.scielo.br/scielo.php?script=sci_arttext\&pid=S0102-311X2013001200009 \&lng=pt\&nrm=iso\&tlng=pt $>$. Acesso em: 13 set. 2017.

- Busca explorar a experiência relativa à assistência ao parto recebida em um centro de parto normal. Como método de pesquisa, utilizou-se a análise indutiva e interpretativa das narrativas de 17 mulheres, que resultou em diferentes categorias descritivas. A assistência ao parto foi avaliada positivamente pelas mulheres, e esse resultado fornece sustentação à política pública de expansão dos centros de parto normal.

70. LEAL, Maria do Carmo; GAMA, Silvana Granado Nogueira da; CUNHA, Cynthia Braga da. Desigualdades raciais, sociodemográficas e na assistência ao pré-natal e ao parto, 1999-2001. Revista de Saúde Pública, v.39, n.1, p.100-107. 2005. Disponível: <http://www.scielo.br/scielo.php?script=sci_arttext\&pid=S0034$89102005000100013 \&$ Ing=pt\&nrm=iso\&tlng=pt>. Acesso em: 6 set. 2017.

- Analisa as desigualdades sociais no acesso e utilização dos serviços de saúde em relação à cor da pele em amostra representativa de puérperas que demandaram atenção hospitalar ao parto. Trata-se de estudo transversal, realizado no município do Rio de Janeiro, no qual foram amostradas 9.633 puérperas. Verificaram-se dois níveis de discriminação, a educacional e a racial, que perpassam a esfera da atenção oferecida pelos serviços de saúde à população de puérperas do município do Rio de Janeiro.

71. LEÃO, Míriam Rêgo de Castro; BASTOS, Marisa Antonini Ribeiro. Doulas apoiando mulheres durante o trabalho de parto: experiência do Hospital Sofia Feldman. Revista Latino-Americana de Enfermagem, v.9, n.3, p.90-94. 2001. Disponível em: <http://www.scielo.br/scielo.php?script=sci_arttext\&pid=S0104$11692001000300014 \&$ Ing=pt\&nrm=iso\&tlng=pt>. Acesso em: 22 ago. 2017.

- Visa fazer uma revisão da literatura sobre suporte intraparto realizado por doulas e relatar a experiência de um hospital filantrópico de nível secundário.

72. LEÃO, Míriam Rêgo de Castro; RIESCO, Maria Luiza Gonzalez; SCHNECK, Camilla Alexsandra; ANGELO, Margareth. Reflexões sobre o excesso de cesarianas no Brasil e a autonomia das mulheres. Ciência \& Saúde Coletiva, v.18, n.8, p.2.395-2.400. 2013. Disponível em: <http://www.scielo.br/scielo.php?script=sci_ arttext\&pid=S1413-81232013000800024\&lng=pt\&nrm=iso\&tlng=pt $>$. Acesso em: 14 set. 2017.

- Busca refletir sobre o excesso de cesarianas no Brasil, em uma perspectiva crítica e propositiva. Dados sobre taxas de cesariana e estudos acerca da preferência das mulheres a respeito da via de parto são discutidos com a finalidade de contribuir para o debate sobre autonomia das usuárias do sistema de saúde. Além disso, discutem-se as redes e os movimentos sociais como possíveis facilitadores da autonomia das mulheres, na medida em que possibilitam apoio mútuo e compartilhamento de experiências, contribuindo para a construção de relações mais igualitárias entre as mulheres e os profissionais de saúde.

73. LEGUIZAMON JUNIOR, Teodoro; STEFFANI, Jovani Antônio; BONAMIGO, Elcio Luiz. Escolha da via de parto: expectativa de gestantes e obstetras. Revista Bioética, v.21, n.3, p.509-517. 2013. Disponível em: <http:// www.scielo.br/scielo.php?script=sci_arttext\&pid=S1983-80422013000300015\&lng=pt\&nrm=iso\&tlng= pt>. Acesso em: 14 set. 2017.

- Identifica a expectativa de gestantes e médicos obstetras quanto à via de parto por meio de estudo quantitativo descritivo e transversal. A maioria das gestantes $(74,1 \%)$ manifestou preferência 
pelo parto natural, sobretudo as católicas e portadoras de ensino superior completo ou médio incompleto. Entre os obstetras houve preferência pelo parto cesariano $(58,3 \%)$ e, se fossem instados a aconselhar, todos $(100 \%)$ recomendariam parto natural. Caso fossem solicitados a realizar cesariana a pedido, $54,5 \%$ dos obstetras concordariam de imediato, porém somente $27,3 \%$ admitiriam este direito para gestantes do sistema público de saúde.

74. LEISTER, Nathalie; RIESCO, Maria Luiza Gonzalez. Assistência ao parto: história oral de mulheres que deram à luz nas décadas de 1940 a 1980. Texto \& Contexto-Enfermagem, v.22, n.1, p.166-174. 2013. Disponível em: $<$ http://www.scielo.br/scielo.php?script=sci_arttext\&pid=S0104-07072013000100020\&lng=pt\&nrm=iso\&tl $\mathrm{ng}=\mathrm{pt}>$. Acesso em: 14 set. 2017.

- Busca compreender as transformações no modelo de assistência ao parto a partir da experiência de mulheres que deram à luz no estado de São Paulo nas décadas de 1940 a 1980 . Os resultados indicaram uma demarcação geracional e temporal nos anos 1970. Os partos nas décadas de 1940 a 1960 ocorreram no contexto de transição da assistência domiciliar para hospitalar. A década de 1980 representa um momento de inflexão dos elementos que compõem o modelo assistencial, como tipo e local do parto e profissional que assiste à mulher, com incremento da tecnologia e das intervenções obstétricas.

75. LEISTER, Nathalie. Transformações no modelo assistencial ao parto: história oral de mulheres que deram à luz nas décadas de 1940 a 1980. Cadernos de História da Ciência, v.7, n.2, p.117-119. 2011. Disponível em: $<$ http://periodicos.ses.sp.bvs.br/scielo.php?script=sci_arttext\&pid=\$1809-76342011000200009\&lng=pt\&nr $\mathrm{m}=$ iso $>$. Acesso em: 16 set. 2017.

- Busca compreender as transformações no modelo de assistência ao parto a partir da experiência de mulheres que deram à luz no estado de São Paulo nas décadas de 1940 a 1980 e que são mães, avós e bisavós de egressos da primeira turma do curso de Obstetrícia da Escola de Artes, Ciências e Humanidades da Universidade de São Paulo. Estudo descritivo, segundo o método da história oral temática. Os resultados mostraram que as mulheres tiveram 49 partos no período estudado. Os resultados indicaram uma demarcação geracional e temporal nos anos 1970.

76. LEITE, Ana Cristina da Nóbrega Marinho Torres; PAES, Neir Antunes. Direitos femininos no Brasil: um enfoque na saúde materna. História, Ciências, Saúde - Manguinhos, v.16, n.3, p.705-714. 2009. Disponível em: <http:// www.scielo.br/scielo.php?script=sci_arttext\&pid=S0104-59702009000300008\&lng=pt\&nrm=iso\&tIng= pt>. Acesso em: 29 ago. 2017.

- Aborda a trajetória dos direitos femininos em saúde no Brasil, do período pós-guerra até os dias atuais, com foco na saúde materna, por meio de levantamento histórico das iniciativas mais amplas do poder público no âmbito da saúde da mulher e da implantação de ações voltadas para assistência à gravidez, ao parto e puerpério, de estímulo à amamentação e de medidas dirigidas às mulheres durante o período reprodutivo.

77. LESSA, Heloisa Ferreira; TYRRELL, Maria Antonieta Rubio; ALVES, Valdecyr Herdy; RODRIGUES, Diego Pereira. Informação para a opção pelo parto domiciliar planejado: um direito de escolha das mulheres. Texto \& Contexto - Enfermagem, v.23, n.3, p.665-672. 2014. Disponivel em: <http://www.scielo.br/scielo.php?script=sci arttext\&pid=S0104-07072014000300665\&lng=pt\&nrm=iso\&tlng=pt>. Acesso em: 14 set. 2017 .

- Descreve o processo de opção das mulheres pelo parto domiciliar planejado. De entrevistas com 17 mulheres que pariram no domicílio entre 2008 e 2010 no Rio de Janeiro, selecionou-se uma categoria: informação - um passo para a opção pelo parto domiciliar planejado. Essa categoria foi construída a partir de seis subcategorias: conhecia pessoas que tiveram parto domiciliar; conhecia pessoas com experiências negativas; internet como fonte de informação; livros como fonte de informação, informações a partir de profissional de saúde; e troca de informações entre mulheres. A informação atua como rede de conhecimento, relatos e experiências em suas dimensões simbólicas, favorecendo a conscientização e organização social de apoio. 
78. LOPES, Rita de Cássia Sobreira; DONELLI, Tagma Schneider; LIMA, Carolina Mousquer; PICCININI, Cesar A. $\mathrm{O}$ antes e o depois: expectativas e experiências de mães sobre o parto. Psicologia: Reflexão e Crítica, v.18, n.2, p.247-254. 2005. Disponível em: <http://www.scielo.br/scielo.php?script=sci_arttext\&pid=S0102$79722005000200013 \&$ Ing=pt\&nrm=iso\&tlng=pt>. Acesso em: 6 set. 2017.

- Investiga as expectativas e o posterior relato da experiência do parto de 28 mulheres primíparas, com idades entre 20 e 37 anos. Análise de conteúdo qualitativa indicou que as mães relatam, durante a gestação, tanto expectativas positivas como negativas em relação ao parto, no que diz respeito a si própria e ao bebê. Já em relação à experiência do parto, houve uma tendência à polarização, com algumas mães relatando apenas sentimentos positivos e outras apenas sentimentos negativos. Os relatos mostram que o parto se constitui em um evento que perpassa todo o processo de gestação e puerpério, marcando profundamente a história da mãe.

79. LUZ, Lia Hecker; GICO, Vânia de Vasconcelos. Blogs como canais alternativos de comunicação para o renascimento do parto. Intercom: Revista Brasileira de Ciências da Comunicação, v.39, n.2, p.147-160. 2016. Disponível em: <http://www.scielo.br/scielo.php?script=sci_arttext\&pid=S1809-58442016000200147\&lng $=$ pt\&nrm=iso\&tlng=pt>. Acesso em: 16 set. 2017.

- Investiga a blogosfera brasileira da humanização do parto composta por blogs mantidos por mulheres ativistas. A partir da análise qualitativa de um blog expressivo desse universo, explora como os sites de redes sociais (SNS, em sua sigla em inglês) estão sendo usados como canais alternativos de comunicação e informação para facilitar ações coletivas e o engajamento civil. Conclui-se que as ferramentas da internet têm permitido uma mobilização inédita em prol do renascimento do parto, de forma a garantir um atendimento mais humano e menos violento, baseado em evidências científicas.

80. MACHADO, Nilce Xavier de Souza; PRAÇA, Neide de Souza. Centro de parto normal e a assistência obstétrica centrada nas necessidades da parturiente. Revista da Escola de Enfermagem da USP, v.40, n.2, p.274-279. 2006. Disponível em: <http://www.scielo.br/scielo.php?script=sci_arttext\&pid=S0080-62342006000200017\&lng $=p t \& n r m=i s o \& t \operatorname{lng}=p t>$. Acesso em: 24 ago. 2017.

- Procura divulgar a proposta das autoras de substituição da expressão "assistência humanizada ao parto" por "assistência obstétrica centrada nas necessidades da parturiente" e discorrer sobre como essa assistência é prestada no Centro de Parto Normal do Hospital Geral de Itapecerica da Serra (SP).

81. MALHEIROS, Paolla Amorim; ALVES, Valdecyr Herdy; RANGEL, Tainara Seródio Amim; VARGENS, Octavio Muniz da Costa. Parto e nascimento: saberes e práticas humanizadas. Texto \& Contexto - Enfermagem, v.21, n.2, p.329-337. 2012. Disponível em: <http://www.scielo.br/scielo.php?script=sci_arttext\&pid=S010407072012000200010\&lng=pt\&nrm=iso\&tlng=pt>. Acesso em: 31 ago. 2017.

- Pesquisa qualitativa do tipo descritivo-exploratória realizada na Maternidade do Hospital Universitário Antônio Pedro com 16 profissionais de saúde, entre médicos obstetras e enfermeiros obstetras. Busca descrever os conceitos instituídos pelos profissionais de saúde que atuam na atenção ao parto e nascimento sobre a humanização do parto, identifica saberes e práticas da humanização do parto e nascimento e avalia a implementação dos saberes e práticas na assistência ao parto e nascimento e sua relação com a humanização. Diferentemente de outros estudos, como apontam os autores, conclui que os profissionais detêm conhecimentos acerca das políticas de saúde que dispõem sobre a humanização do parto e nascimento, seguem esses preceitos, e sua prática profissional vai ao encontro do que é preconizado pelas políticas.

82. MARQUE, Flavia Carvalho; DIAS, leda Maria Vargas; AZEVEDO, Leila. A percepção da equipe de enfermagem sobre humanização do parto e nascimento. Escola Anna Nery, v.10, n.3, p.439-447. 2006. Disponível em: <http://www.scielo.br/scielo.php?script=sci_arttext\&pid=\$1414-81452006000300012\&lng=pt\&nrm=iso\&tl $\mathrm{ng}=\mathrm{pt}>$. Acesso em: 24 ago. 2017. 
- Trata-se de uma pesquisa qualitativa de abordagem descritiva, que discute a percepção da equipe de enfermagem sobre a humanização do parto e nascimento. Participaram como depoentes do estudo profissionais da área de enfermagem que atuam em sala de parto de duas instituições públicas da cidade do Rio de Janeiro.

83. MARTINS, Aline de Carvalho; BARROS, Geiza Martins. Parirás na dor? Revisão integrativa da violência obstétrica em unidades públicas brasileiras. Revista Dor, v.17, n.3, p.215-218. 2016. Disponível em: <http:// www.scielo.br/scielo.php?script=sci_arttext\&pid=\$1806-00132016000300215\&lng=pt\&nrm=iso\&tlng= pt>. Acesso em: 15 set. 2017.

- Visa proporcionar maior visibilidade às discussões acerca da violência obstétrica sofrida por mulheres brasileiras nas instituições de saúde pública. Foi feita uma revisão integrativa da última década, em que foram analisados cem artigos, para identificar como a violência obstétrica vem se apresentando nas unidades de saúde pública brasileiras. Os tipos de violências obstétricas identificadas foram: violência institucional, violência moral, violência física, violência sexual, violência psicológica e violência verbal.

84. MARTINS, Ana Paula Vosne. Memórias maternas: experiências da maternidade na transição do parto doméstico para o parto hospitalar. História Oral, v.8, n.2, p.61-76. 2005. Disponível em: <http://revista. historiaoral.org.br/index.php?journal=rho\&page =article\&op=view\&path $\% 5 B \% 5 \mathrm{D}=174 \&$ path $\% 5 \mathrm{~B} \%$ 5D=179>. Acesso em: 17 set. 2017.

- Trata da produção da memória materna para uma geração de mulheres que viveu a experiência da maternidade no período em que o Estado brasileiro deu início às políticas de saúde e assistência materno-infantil, entre as décadas de 1930 e 1940 . São mulheres com mais de 75 anos que narram suas experiências da gravidez, do parto e da criação dos filhos, apresentando uma versão da história da maternidade diferente daquela produzida pelos especialistas.

85. MARTINS, Ana Paula Vosne. Uma historiadora militante: Maria Lúcia Mott (1948-2011). Cadernos de Pesquisa, v.43, n.150, p.1.042-1.053. 2013. Disponível em: <http://www.scielo.br/scielo.php?script=sci_ arttext\&pid=S0100-15742013000300016\&lng=pt\&nrm=iso\&tlng=pt $>$. Acesso em: 13 set. 2017.

- Trata-se de uma homenagem à memória de Maria Lúcia Mott, historiadora que tem seu nome e sua produção acadêmica ligados à história das mulheres e, particularmente, à história do parto, das parteiras, das instituições de saúde e da filantropia. Partindo da trajetória acadêmica da historiadora, coloca-se em relevo os temas de seus estudos e as principais publicações que a destacaram como uma pesquisadora incansável, criativa e comprometida com a investigação histórica.

86. MCCALLUM, Cecilia; REIS, Ana Paula dos. Ressignificando a dor e superando a solidão: experiências do parto entre adolescentes de classes populares atendidas em uma maternidade pública de Salvador, Bahia, Brasil. Cadernos de Saúde Pública, v.22, n.7, p.1.483-1.491. 2006. Disponível em: <http://www.scielo.br/scielo. php?script=sci_arttext\&pid=S0102-311X2006000700012\&lng=pt\&nrm=iso\&tlng=pt $>$. Acesso em: 7 set. 2017.

- Examina o parto em uma maternidade pública de Salvador, com base na perspectiva de mulheres jovens e adolescentes, a maioria das quais negras e de classes populares. O estudo, de caráter antropológico, baseia-se na análise de entrevistas e na etnografia do hospital, particularmente do centro obstétrico. As mulheres descrevem o trabalho de parto como dominado pelo medo, solidão e dor, sensações que se transformam em amor com o nascimento da criança.

87. MEDEIROS, Aline da Silva. A dinâmica hospitalar da Maternidade Dr. João Moreira, em Fortaleza, nas primeiras décadas do século XX. História, Ciências, Saúde - Manguinhos, v.20, n.3, p.963-981. 2013. Disponível em: $<$ http://www.scielo.br/scielo.php?script=sci_arttext\&pid=S0104-59702013000300963\&lng=pt\&nrm=is o\&tlng=pt $>$. Acesso em: 16 set. 2017. 
- Analisa dinâmicas internas da Maternidade Dr. João Moreira, em Fortaleza: sua organização espacial, seus regimes de cura e disciplina, sua relação com as pacientes, sua equipe hospitalar etc. A consulta de registros estatísticos e de casos clínicos produzidos por médicos auxiliou o estudo deste que foi um dos principais marcos do desenvolvimento da obstetrícia no Ceará.

88. MEDEIROS, Renata Marien Knupp; SANTOS, Inês Maria Meneses dos; SILVA, Leila Rangel da. A escolha pelo parto domiciliar: história de vida de mulheres que vivenciaram esta experiência. Escola Anna Nery, v.12, n.4, p.765-772. 2008. Disponivel em: <http://www.scielo.br/scielo.php?script=sci_arttext\&pid=S1414$81452008000400022 \&$ lng=pt\&nrm=iso\&tlng=pt>. Acesso em: 28 ago. 2017.

- Procura analisar os fatores que influenciaram a escolha pelo parto domiciliar, assistido por enfermeira obstetra, a partir da história de vida das mulheres que o vivenciaram. Todas as entrevistadas fizeram referência às experiências de parto de suas mães, evidenciando a influência destas na construção de suas escolhas. Esse grupo buscou informações; enfrentou tanto o modelo tecnocrático vigente como suas famílias; encontrou atendimento ao parto humanizado no ambiente acolhedor domiciliar. Conclui-se que o vínculo entre a enfermeira obstétrica e sua cliente, bem como o respeito por suas escolhas, expectativas e cultura proporcionaram segurança e confiabilidade às mulheres.

89. MEDEIROS, Renata Marien Knupp; TEIXEIRA, Renata Cristina; NICOLINI, Ana Beatriz; ALVARES, Aline Spanevello; CORRÊA, Áurea Christina de Paula; MARTINS, Débora Prado. Cuidados humanizados: a inserção de enfermeiras obstétricas em um hospital de ensino. Revista Brasileira de Enfermagem, v.69, n.6, p.1.091-1.098. 2016. Disponível em: <http://www.scielo.br/scielo.php?script=sci_arttext\&pid=S0034$71672016000601091 \&$ Ing=pt\&nrm=iso\&tlng=pt>. Acesso em: 15 set. 2017.

- Analisa a assistência prestada em uma unidade de pré-parto/parto/pós-parto de um hospital de ensino após a inserção de enfermeiras obstétricas. A amostra foi composta por dados relativos a 701 partos normais ocorridos entre os anos de 2014 e 2016. Os resultados sugerem que a inserção das enfermeiras obstétricas contribuiu para a qualificação do cuidado prestado ao parto e ao nascimento, uma vez que ocorreu a redução de intervenções, tais como a episiotomia e as cesarianas, havendo o incentivo ao uso de práticas que não interferem na fisiologia do processo parturitivo, gerando bons resultados perinatais.

90. MELLEIRO, Marta Maria; GUALDA, Dulce Maria Rosa. Experiências e expressões de gestantes na interação com o sistema de saúde: um enfoque fotoetnográfico. Revista Latino-Americana de Enfermagem, v.12, n.3, p.503-510. 2004. Disponível em: <http://www.scielo.br/scielo.php?script=sci_arttext\&pid=S0104$11692004000300008 \&$ Ing=pt\&nrm=iso\&tlng=pt $>$. Acesso em: 6 set. 2017.

- Procura compreender a experiência da mulher no seu contato com o sistema de saúde por ocasião do parto. Adotou-se como referencial teórico-metodológico a antropologia cultural e a etnografia. A coleta de dados foi realizada por meio da observação participante, do recurso fotográfico e da entrevista. As fotografias foram realizadas por gestantes cujo pré-natal foi realizado nas Unidades Básicas de Saúde da área de abrangência do hospital-escola, cenário cultural desta investigação. Os achados deste estudo possibilitaram uma visão compreensiva do conhecimento cultural das colaboradoras com relação à sua interação com o sistema de saúde, bem como de suas expectativas no ciclo gravídico-puerperal.

91. MELLER, Fernanda de Oliveira; SCHÄFER, Antônio Augusto. Fatores associados ao tipo de parto em mulheres brasileiras: PNDS 2006. Ciência \& Saúde Coletiva, v.16, n.9, p.3.829-3.835. 2011. Disponível em: <http://www. scielo.br/scielo.php?script=sci_arttext\&pid=\$1413-81232011001000018\&lng=pt\&nrm=iso\&tlng=pt $>$. Acesso em: 12 set. 2017.

- Analisa a prevalência dos tipos de parto e fatores associados em mulheres brasileiras em idade fértil estudadas na última Pesquisa Nacional de Demografia e Saúde (PNDS). O estudo compreende um recorte da PNDS - estudo transversal, de base domiciliar, de âmbito nacional, 
que teve como objetivo central caracterizar a população feminina em idade fértil e as crianças menores de 5 anos. Foram descritas as prevalências de tipo de parto segundo as seguintes variáveis de exposição: macrorregiões brasileiras, situação de domicílio, idade, cor da pele, estado nutricional, escolaridade, local do pré-natal e local do parto.

92. MERIGHI, Miriam Aparecida Barbosa; CARVALHO, Geraldo Mota de; SULETRONI, Vivian Pontes. O processo de parto e nascimento: visão das mulheres que possuem convênio saúde na perspectiva da fenomenologia social. Acta Paulista de Enfermagem, v.20, n.4, p.434-440. 2007. Disponível em: <http://www.scielo.br/scielo. php?script=sci_arttext\&pid=S0103-21002007000400008\&lng=pt\&nrm=iso\&tlng=pt>. Acesso em: 7 set. 2017. - Procura compreender o processo de parto e nascimento na perspectiva das mulheres que possuem convênio saúde. A partir de questões norteadoras, analisam-se os dados segundo o referencial da fenomenologia social. Os resultados mostraram que essas mulheres puderam opinar sobre o tipo de parto, contar com a presença do marido na sala de parto e confiar no profissional que as assistiu. Para essas mulheres, a experiência foi gratificante.

93. MERIGHI, Miriam Aparecida Barbosa; GUALDA, Dulce Maria Rosa. O cuidado à saúde materna no Brasil e o resgate do ensino de obstetrizes para assistência ao parto. Revista Latino-Americana de Enfermagem, v.17, n.2, p.265-270. 2009. Disponivel em: <http://www.scielo.br/scielo.php?script=sci_arttext\&pid=S0104$11692009000200020 \&$ Ing=pt\&nrm=iso\&tlng=pt>. Acesso em: 10 set. 2017.

- Apresenta uma breve análise da situação do cuidado com a saúde materna no Brasil e, com base nesses dados, aponta as transformações no modelo de assistência à mulher e às famílias e propõe algumas medidas, as quais incluem a inserção do trabalho da enfermeira obstétrica ou obstetriz no contexto atual. Comenta que a tendência atual do processo de nascimento pressupõe a incorporação do paradigma que favorece a fisiologia e a valorização da experiência feminina, a abordagem centrada na família, com ênfase na prevenção, educação e relacionamento interpessoal, sem deixar de lado a segurança. Considera que o modelo de cuidado com a saúde, que inclui o trabalho da obstetriz, pode melhorar os indicadores de saúde materna.

94. MOLITERNO, Aline Cardoso Machado; BORGHI, Ana Carla; ORLANDI, Larissa Helena de Souza Freire; FAUSTINO, Rosângela Célia; SERAFIM, Deise; CARREIRA, Lígia. Processo de gestar e parir entre as mulheres Kaingang. Texto \& Contexto - Enfermagem, v.22, n.2, p.293-301. 2013. Disponivel em: <http://www.scielo.br/ scielo.php?script=sci_arttext\&pid=S0104-07072013000200004\&lng=pt\&nrm=iso\&tlng=pt $>$. Acesso em: 14 set. 2017.

- Identifica o processo de gestação e nascimento entre as mulheres Kaingang. Pesquisa qualitativa de abordagem etnográfica, realizada com trinta mulheres, na Terra Indígena de Faxinal, em Catanduvas (PR). A concepção de parto tem mudado com o passar das gerações, sendo que as mulheres mais velhas acreditam ser melhor parir acocorada em casa, e as mulheres mais novas demonstram insegurança de ter os filhos fora do hospital. Foi identificada insatisfação na assistência durante o parto. É necessária a adequação das práticas de forma a preservar a cultura da etnia sem a exposição de mulheres e recém-nascidos ao risco de complicações ou mortalidade.

95. MOTT, Maria Lucia (Org.). Bibliografia comentada sobre a assistência ao parto no Brasil (1972-2002). Revista Estudos Feministas, v.10, n.2, p.493-507. 2002. Disponível em: <http://www.scielo.br/scielo.php?script=sci_ arttext\&pid=S0104-026X2002000200017\&lng=pt\&nrm=iso\&tlng=pt>. Acesso em: 22 ago. 2017.

- A organização da bibliografia visou: (1) divulgar trabalhos sobre a assistência ao parto no Brasil, produzidos em diferentes áreas de conhecimento (história, antropologia, enfermagem, medicina, assistência social, psicologia e sociologia); (2) colocar em contato pesquisadores que trabalham o tema; (3) dar espaço para assuntos, abordagens e autores não contemplados no dossiê. Foram referenciados e resumidos 77 trabalhos (artigos, dissertações, teses, relatórios, cartilha), produzidos por cerca de cinquenta autores, publicados ou realizados entre 1972 e 2002. 
96. MOTT, Maria Lúcia. As parteiras e a assistência ao parto em São Paulo nas primeiras décadas do século XX. Revista do Instituto Histórico e Geográfico Brasileiro, v.163, n.415, p.67-84. 2002. Disponível em: <https://drive. google.com/file/d/OB_G9pg7CxKSsMjN0Vi03OEtwUzg/view>. Acesso em: 17 set. 2017.

- Discute as atribuições das parteiras nas primeiras décadas do século XX, face ao crescente discurso sobre o parto como um evento médico e as maternidades como locais por excelência para as mulheres darem à luz. O artigo se detém nos primeiros cursos para formação de parteiras e na fiscalização da profissão, apontando que, no início do século XX, já se pode perceber uma associação entre parteiras e enfermeiras, não apenas em alguns cursos para formação profissional, mas no cotidiano de trabalho.

97. MOTT, Maria Lúcia. Assistência ao parto: do domicílio ao hospital (1830-1960). Projeto História, v.25, p.197219. 2002. Disponível em: <https://revistas.pucsp.br/index.php/revph/article/view/10588/7878>. Acesso em: 17 set. 2017.

- Busca contribuir para o debate atual sobre a assistência ao parto no Brasil. Faz um retrospecto dos principais modelos de atendimento ao parto no país, com destaque para os estados do Rio de Janeiro, Bahia e São Paulo.

98. MOTT, Maria Lúcia. Fiscalização e formação das parteiras em São Paulo (1880-1920). Revista da Escola de Enfermagem da USP, v.35, n.1, p.46-53. 2001. Disponível em: <http://www.scielo.br/scielo.php?script=sci_ arttext\&pid=S0080-62342001000100008\&lng=pt\&nrm=iso\&tlng=pt>. Acesso em: 17 set. 2017.

- Procura refletir sobre as atribuições de parteiras e enfermeiras obstétricas e a exclusão dessas profissionais na assistência ao parto no decorrer do século XX. O artigo se detém nos primeiros cursos para formação de parteiras e na fiscalização da profissão, apontando que, no início do século XX já se pode perceber uma associação entre parteiras e enfermeiras, não apenas em alguns cursos para formação profissional, mas no cotidiano de trabalho. Passa a existir a expectativa de que a parteira fosse também enfermeira.

99. MOURA, Fernanda Maria de Jesus S. Pires; CRIZOSTOMO, Cilene Delgado; NERY, Inez Sampaio; MENDONÇA, Rita de Cássia Magalhães; ARAÚJO, Olívia Dias de; ROCHA, Silvana Santiago da. A humanização e a assistência de enfermagem ao parto normal. Revista Brasileira de Enfermagem, v.60, n.4, p.452-455. 2007. Disponível em: $<$ http://www.scielo.br/scielo.php?script=sci_arttext\&pid=S0034-71672007000400018\&lng=pt\&nrm=iso\&tl $\mathrm{ng}=\mathrm{pt}>$. Acesso em: 25 ago. 2017.

- Busca identificar a produção científica sobre humanização e assistência de enfermagem ao parto normal. As fontes foram artigos científicos da base de dados da Scielo-Brasil, período 2000 a 2007. A análise apontou que o paradigma atual é centralizado na intervenção do parto, apesar do movimento da humanização defender o parto natural e fisiológico realizado por enfermeira.

100. MOUTA, Ricardo José Oliveira; PROGIANTI, Jane Márcia. Estratégias de luta das enfermeiras da Maternidade Leila Diniz para implantação de um modelo humanizado de assistência ao parto. Texto \& Contexto Enfermagem, v.18, n.4, p.731-740. 2009. Disponível em: <http://www.scielo.br/scielo.php?script=sci_ arttext\&pid=S0104-07072009000400015\&lng=pt\&nrm=iso\&tlng=pt>. Acesso em: 29 ago. 2017.

- Visa identificar as estratégias de luta simbólica das enfermeiras da Maternidade Leila Diniz para a implantação de um modelo humanizado de assistência ao parto e analisar os efeitos da luta. Concluiu-se que as estratégias de luta desenvolvidas por esses agentes contribuíram para que as enfermeiras obstétricas conquistassem na maternidade posição hierárquica para o desenvolvimento de práticas obstétricas do modelo humanizado.

101. NAGAHAMA, Elizabeth Eriko Ishida; SANTIAGO, Sílvia Maria. A institucionalização médica do parto no Brasil. Ciência e Saúde Coletiva, v.10, n.3, p.651-657.2005. Disponível em: <http://www.scielo.br/scielo.php?script=sci_ arttext\&pid=S1413-81232005000300021\&lng=pt\&nrm=iso\&tlng=pt>. Acesso em: 17 set. 2017.

- Aborda o conceito de institucionalização da atenção à saúde, em especial da saúde da mulher, como forma de poder hegemônico na atenção, especificamente na assistência institucional 
ao parto. Descreve as estratégias de implantação da hegemonia institucional sobre o corpo feminino, exercidas através das políticas de saúde e das práticas de atenção médica. O poder do Estado na institucionalização da atenção é registrado no decurso da reconstrução histórica dos programas de saúde maternoinfantil das décadas de 1920 a 1980, na qual se identificou que o controle ideológico sobre a saúde das mulheres traduziu-se em formas de controle de sua sexualidade como veículo da reprodução.

102. NAGAHAMA, Elizabeth Eriko Ishida; SANTIAGO, Silvia Maria. Práticas de atenção ao parto e os desafios para humanização do cuidado em dois hospitais vinculados ao Sistema Único de Saúde em município da região Sul do Brasil. Cadernos de Saúde Pública, v.24, n.8, p.1.859-1.868. 2008. Disponível em: <http://www.scielo. $\mathrm{br} / \mathrm{scielo}$.php?script=sci_arttext\&pid=S0102-311X2008000800014\&lng=pt\&nrm=iso\&tlng=pt $>$. Acesso em: 28 ago. 2017.

- Caracteriza a assistência hospitalar ao parto em dois hospitais vinculados ao Sistema Único de Saúde no Paraná e identifica obstáculos e aspectos facilitadores para implantação do cuidado humanizado, pautando-se na percepção das mulheres sobre a atenção recebida. Os dados apontaram para um modelo assistencial marcado pelo peso da herança higienista nas rotinas hospitalares e nas práticas profissionais, centrado no profissional médico como condutor do processo.

103. NAGAHAMA, Elizabeth Eriko Ishida; SANTIAGO, Silvia Maria. Humanização e equidade na atenção ao parto em município da região Sul do Brasil. Acta Paulista de Enfermagem, v.21, n.4, p.609-615. 2008. Disponível em: $<$ http://www.scielo.br/scielo.php?script=sci_arttext\&pid=S0103-21002008000400012\&lng=pt\&nrm=iso\&tl $\mathrm{ng}=\mathrm{pt}>$. Acesso em: 10 set. 2017.

- Procura identificar fatores associados à qualidade da atenção e possíveis predisponentes de iniquidades no cuidado ao parto, a partir das características sociodemográficas e obstétricas de mulheres atendidas em dois hospitais vinculados ao Sistema Único de Saúde no município de Maringá (PR). Três características compuseram o perfil da parturiente que se beneficiou de atenção mais qualificada: ter menos de 19 anos, ensino médio completo e não ter antecedentes de cesariana.

104. NAGAHAMA, Elizabeth Eriko Ishida; SANTIAGO, Silvia Maria. Parto humanizado e tipo de parto: avaliação da assistência oferecida pelo Sistema Único de Saúde em uma cidade do sul do Brasil. Revista Brasileira de Saúde Materno Infantil, v.11, n.4, p.415-425. 2011. Disponível em: <http://www.scielo.br/scielo.php?script=sci_ arttext\&pid=\$1519-38292011000400008\&lng=pt\&nrm=iso\&tlng=pt $>$. Acesso em: 12 set. 2017.

- Avalia a qualidade da atenção ao parto nos dois hospitais de referência para atendimento ao parto no Sistema Único de Saúde no município de Maringá (PR). Os hospitais obtiveram desempenho classificado como regular e resultado da assistência insatisfatório, determinado pelas altas taxas de cesarianas.

105. NAKANO, Andreza Rodrigues; BONAN, Claudia; TEIXEIRA, Luiz Antônio. A normalização da cesárea como modo de nascer: cultura material do parto em maternidades privadas no Sudeste do Brasil. Physis: Revista de Saúde Coletiva, v.25, n.3, p.885-904. 2015. Disponível em: <http://www.scielo.br/scielo.php?script=sci_ arttext\&pid=S0103-73312015000300885\&lng=pt\&nrm=iso\&tlng=pt $>$. Acesso em: 15 set. 2017.

- Discute o desenvolvimento de uma cultura material em torno do parto e do nascimento em um contexto de utilização maciça de inovações tecnocientíficas e explora a hipótese da normalização da cesariana como modo de nascer, por meio da análise de relatos de mulheres que realizaram cesáreas em maternidades privadas do Rio de Janeiro e São Paulo. O procedimento cirúrgico é reapresentado como um modo de nascer seguro, limpo, organizado e compatível com a vida moderna, com o trabalho produtivo intenso e com os impedimentos - sociais e biológicos - de se reproduzir nos modos "antigos", figurando como um evento de continuidade, e não de exceção.

106. NAKANO, Andreza Rodrigues; BONAN, Claudia; TEIXEIRA, Luiz Antônio. Cesárea, aperfeiçoando a técnica e normatizando a prática: uma análise do livro Obstetrícia, de Jorge de Rezende. História, Ciências, Saúde 
-Manguinhos, v.23, n.1, p.155-172. 2016. Disponivel em: <http://www.scielo.br/scielo.php?script=sci_ arttext\&pid=S0104-59702016000100155\&lng=pt\&nrm=iso\&tlng=pt>. Acesso em: 16 set. 2017.

- Discute a apropriação e o desenvolvimento das técnicas de cesariana pelos médicos no Brasil, no século XX, analisando o capítulo "Operação cesariana", de três edições do livro-texto Obstetrícia, de Jorge de Rezende. O protagonismo desse autor na obstetrícia criou disposições para a normalização da prática da cesárea. As redes de significados praticadas nessa comunidade científica abarcam uma "disposição para um sentir e para um agir" (Fleck) que balizam a cesárea como um parto "normal": manifesta normas que excluem imprevisibilidade, descontrole, caos, perigos associados à fisiologia do parto, atendendo à exigência de controle, disciplinamento e segurança, atributos associados às práticas técnicas e tecnológicas da biomedicina

107. NARCHI, Nádia Zanon; CRUZ, Elizabete Franco; GONÇALVES, Roselane. O papel das obstetrizes e enfermeiras obstetras na promoção da maternidade segura no Brasil.Ciência\& Saúde Coletiva, v.18, n.4, p.1.059-1.068.2013. Disponivel em: <http://www.scielo.br/scielo.php?script=sci_arttext\&pid=\$1413-81232013000400019\&lng $=$ pt\&nrm=iso\&tling=pt $>$. Acesso em: 14 set. 2017.

- Procura oferecer subsídios teóricos que sustentem a proposta de que a promoção da maternidade segura requer a efetiva participação de obstetrizes e enfermeiras obstetras, profissionais que, a partir da perspectiva da promoção da saúde, podem colaborar na constituição de uma rede efetiva de cuidados, cuja premissa básica seja a atenção humanizada e baseada em evidências científicas a fim de melhorar a experiência da mulher e da família no processo de gestação, parto e pós-parto.

108. NASCIMENTO, Keyla Cristiane do; SANTOS, Evanguelia Kotzias Atherino dos; ERDMANN, Alacoque Lorenzini; NASCIMENTO JÚNIOR, Hélio José do; CARVALHO, Jacira Nunes. A arte de partejar: experiência de cuidado das parteiras tradicionais de Envira (AM). Escola Anna Nery, v.13, n.2, p.319-327. 2009. Disponível em: <http:// www.scielo.br/scielo.php?script=sci_arttext\&pid=S1414-81452009000200012\&lng=pt\&nrm=iso\&tlng= pt>. Acesso em: 10 set. 2017.

- Trata-se de um estudo exploratório-descritivo de caráter qualitativo que retrata as parteiras tradicionais de Envira, município do estado do Amazonas, onde $80 \%$ dos partos são feitos por elas. Objetiva caracterizar a experiência de cuidado no partejar dessas parteiras. Participaram do estudo 29 parteiras. Conclui-se que há um longo caminho a percorrer na reversão dos quadros de doenças, pobreza e abandono, um caminho no qual as parteiras treinadas poderão desempenhar importante papel, na medida em que atingem muitas mulheres, configurando-se como multiplicadoras concretas de conhecimentos.

109. NASCIMENTO, Natália Magalhães do; PROGIANTI, Jane Márcia; NOVOA, Rachelli lozzi; OLIVEIRA, Thalita Rocha de; VARGENS, Octávio Muniz da Costa. Tecnologias não invasivas de cuidado no parto realizadas por enfermeiras: a percepção de mulheres. Escola Anna Nery, v.14, n.3, p.456-461. 2010. Disponível em: <http:// www.scielo.br/scielo.php?script=sci_arttext\&pid=S1414-81452010000300004\&lng=pt\&nrm=iso\&tlng= pt>. Acesso em: 30 ago. 2017.

- Identifica as atitudes e práticas de enfermeiras obstétricas e discute seus efeitos durante o trabalho de parto na percepção de mulheres atendidas em uma casa de parto. A análise dos dados evidenciou que as mulheres reconheceram a atitude carinhosa e práticas como a livre movimentação corporal e o estímulo à presença de um acompanhante como as principais tecnologias não invasivas utilizadas durante o trabalho de parto.

110. NILSEN, Evenise; SABATINO, Hugo; LOPES, Maria Helena Baena de Moraes. Dor e comportamento de mulheres durante o trabalho de parto e parto em diferentes posições. Revista da Escola de Enfermagem da USP, v.45, n.3, p.557-565. 2011. Disponivel em: <http://www.scielo.br/scielo.php?script=sci_arttext\&pid=S0080$62342011000300002 \&$ Ing=pt\&nrm=iso\&tlng=pt $>$. Acesso em: 12 set. 2017.

- Avalia a intensidade da sensação dolorosa e o comportamento, durante o trabalho de parto e parto entre mulheres que tiveram parto normal, sem analgesia, nas posições semissentada, 
decúbito lateral esquerdo e litotomia. Observou-se que a dor entre as mulheres que pariram em litotomia foi significativamente menor em comparação com decúbito lateral esquerdo $(p=0,003)$, embora a posição tenha sido escolhida pela mulher. Houve associação entre dor e comportamento. Os resultados indicam uma associação entre posição no parto e sensação dolorosa, mas não foi possível identificar fatores explicativos, sendo necessário desenvolver estudos longitudinais.

111. NOGUEIRA, Adriana Tanese. O parto: encontro com o sagrado. Texto \& Contexto - Enfermagem, v.15, n.1, p.122-130. 2006. Disponível em: <http://www.scielo.br/scielo.php?script=sci_arttext\&pid=S010407072006000100015\&lng=pt\&nrm=iso\&tlng=pt>. Acesso em: 25 ago. 2017.

- Apresenta a questão da humanização do parto em seus fundamentos culturais e antropológicos, com o intuito de acrescentar o ponto de vista não médico ao debate. Baseou-se nos pensamentos de Rudolf Otto e Mircea Eliade, sendo que a malha teórica que estrutura a filosofia e a prática alquímica foi utilizada para analisar a experiência de uma mulher que com quarenta semanas de gestação inverte o roteiro previsto em busca de uma experiência de parto que se revelou extraordinária.

112. NUNES, Isa Maria; FERREIRA, Sílvia Lúcia; PAIVA, Mirian Santos. Condições de trabalho de enfermeiras obstetras: aspectos de uma realidade. Revista Brasileira de Enfermagem, v.55, n.6, p.652-657. 2002. Disponível em: $<$ http://www.scielo.br/scielo.php?script=sci_arttext\&pid=\$0034-71672002000600004\&lng=pt\&nrm=is o\&tlng=pt $>$. Acesso em: 4 set. 2017.

- Descreve as condições de trabalho da enfermeira obstetra, suas especificidades, transformações e contradições. A amostra foi constituída de dez enfermeiras habilitadas e/ou especialistas em enfermagem obstétrica, atuantes em seis instituições públicas de Salvador. Constata-se a existência de muitas inadequações nas condições oferecidas para o trabalho da enfermeira obstetra relacionadas à prestação da assistência à mulher durante o parto.

113. OLIVEIRA, Maria Inês Couto de; DIAS, Marcos Augusto Bastos; CUNHA, Cynthia B.; LEAL, Maria do Carmo. Qualidade da assistência ao trabalho de parto pelo Sistema Único de Saúde, Rio de Janeiro (RJ), 1999-2001. Revista de Saúde Pública, v.42, n.5, p.895-902.2008. Disponível em: <http://www.scielo.br/scielo.php?script=sci_ arttext\&pid=S0034-89102008000500015\&lng=pt\&nrm=iso\&tlng=pt $>$. Acesso em: 8 set. 2017.

- Analisa a qualidade da assistência ao trabalho de parto segundo o risco gestacional e tipo de prestador. De modo geral, as gestantes de baixo risco são submetidas a intervenções desnecessárias e as de alto risco não recebem cuidado adequado. Como consequência, os resultados perinatais são desfavoráveis e as taxas de cesariana e de mortalidade materna são incompatíveis com os investimentos e a tecnologia disponível.

114. OLIVEIRA, Sonia Maria Junqueira Vasconcellos de; RIESCO, Maria Luiza Gonzalez; ROSAS MIYA, Claudia Fumiko; VIDOTTO, Paula. Tipo de parto: expectativas das mulheres. Revista Latino-Americana de Enfermagem, v.10, n.5, p.667-674. 2002. Disponível em: <http://www.scielo.br/scielo.php?script=sci_arttext\&pid=S0104$11692002000500007 \&$ lng=pt\&nrm=iso\&tlng=pt>. Acesso em: 4 set. 2017.

- Busca identificar o tipo de parto esperado pelas mulheres, considerando a via vaginal ou cesariana, e sua justificativa; verificar a ocorrência do tipo de parto, segundo as expectativas dessas mulheres; e comparar a indicação médica da cesariana com o entendimento das mulheres sobre justificativa dessa intervenção. A justificativa mais citada pelas mulheres para esperar o parto normal foi a recuperação pós-parto mais rápida e, para a cesárea, ter tido cesárea anterior. As justificativas apresentadas por 61 mulheres para a realização da cesariana não era coincidente com a indicação médica em $47,5 \%$ dos casos.

115. OLIVEIRA, Zuleyce Maria Lessa Pacheco de; MADEIRA, Anézia Moreira Faria. Vivenciando o parto humanizado: um estudo fenomenológico sob a ótica de adolescentes. Revista da Escola de Enfermagem da USP, v.36, n.2, p.133-140. 2002. Disponivel em: <http://www.scielo.br/scielo.php?script=sci_arttext\&pid=S0080$62342002000200005 \&$ Ing=pt\&nrm=iso\&tlng=pt>. Acesso em: 22 ago. 2017. 
- Busca compreender o que significa para as adolescentes passarem pelo parto dito humanizado, por meio de estudo fenomenológico. Participaram do estudo adolescentes atendidas no Hospital Sofia Feldman, instituição filantrópica sem fins lucrativos em Belo Horizonte (MG). O estudo possibilitou apreender três categorias de análise: (1) pré-parto/parto: o corpo sendo controlado; (2) pré-parto/parto: misto de dor e de prazer; (3) parto humanizado: a assistência esperada e desejada.

116. ORTONA, Concília; FORTES, Paulo Antonio de Carvalho. Jornalistas que escrevem sobre saúde conhecem a humanização do atendimento? Saúde e Sociedade, v.21, n.4, p.909-915. 2012. Disponível em: <http://www. scielo.br/scielo.php?script=sci_arttext\&pid=S0104-12902012000400010\&lng=pt\&nrm=iso\&tlng=pt >. Acesso em: 31 ago. 2017.

- Busca identificar a percepção sobre humanização por parte de alguns jornalistas que escrevem sobre saúde em importantes publicações paulistas, e no que se constitui, na opinião deles, um atendimento humanizado. Conclui-se que os jornalistas pesquisados ainda associam a humanização às primeiras iniciativas de humanização, vinculadas à assistência ao parto e prénatal, além do voluntariado, mas desconhecem a existência de uma política estruturada sobre o tema; consideram o médico como figura essencial à humanização da assistência e desejam que $\mathrm{o}$ atendimento tenha caráter integral.

117. OSAWA, Ruth Hitomi; RIESCO, Maria Luiza Gonzales; TSUNECHIRO, Maria Alice. Parteiras-enfermeiras e enfermeiras-parteiras: a interface de profissões afins, porém distintas. Revista Brasileira de Enfermagem, v.59, n.5, p.699-702. 2006. Disponível em: $<$ http://www.scielo.br/scielo.php?script=sci_arttext\&pid=S0034$71672006000500020 \&$ Ing=pt\&nrm=iso\&tlng=pt>. Acesso em: 24 ago. 2017.

- Procura aprofundar a compreensão do significado da retomada do Curso de Graduação em Obstetrícia da Universidade de São Paulo, no momento atual da assistência ao parto e nascimento. Os eventos do passado que influenciaram nos modelos de assistência ao parto por não médicos foram considerados: a aprovação da lei das parteiras na Inglaterra, em 1902, com a inclusão de sua prática ao sistema de saúde oficial, a marginalização do trabalho da parteira tradicional nos EUA e os momentos emblemáticos das disputas de enfermeiras e obstetrizes (parteiras) no Brasil.

118. PEREIRA, Adriana Lenho de Figueiredo; MOURA, Maria Aparecida Vasconcelos; SOUZA, Ivis Emília de Oliveira; TYRREL, Maria Antonieta Rubio; MOREIRA, Marléa Chagas. Pesquisa acadêmica sobre humanização do parto no Brasil: tendências e contribuições. Acta Paulista de Enfermagem, v.20, n.2, p.205-215. 2007. Disponível em: $<$ http://www.scielo.br/scielo.php?script=sci_arttext\&pid=S0103-21002007000200015\&lng=pt\&nrm=iso\&tl $\mathrm{ng}=\mathrm{pt}>$. Acesso em: 8 set. 2017.

- Apresenta um levantamento das pesquisas acadêmicas brasileiras dos programas de pósgraduação stricto sensu acerca da humanização do parto e nascimento, de forma a identificar a distribuição temporal, regional, por abordagem metodológica e área de conhecimento, e analisar as contribuições dessa produção acadêmica para a prática assistencial. Pesquisa exploratória e descritiva. Os dados foram coletados por meio dos resumos de teses e dissertações disponíveis em bases de dados de bibliotecas virtuais, Bireme e Capes. As pesquisas de pós-graduação propõem mudança de paradigma técnico-científico, na formação profissional, na atitude profissional frente aos direitos humanos e sociais, e uma redefinição de papéis profissionais das enfermeiras e parteiras.

119. PEREIRA, Marina Santos. Associação das Parteiras Tradicionais do Maranhão: relato da assistência ao parto. Saúde e Sociedade, v.25, n.3, p.589-601. 2016. Disponivel em: <http://www.scielo.br/scielo.php?script=sci_ arttext\&pid=S0104-12902016000300589\&lng=pt\&nrm=iso\&tlng=pt $>$. Acesso em: 16 set. 2017.

- Estudo etnográfico sobre o trabalho de assistência ao parto prestado pelas parteiras tradicionais do Maranhão, que atendem gestantes residentes no bairro do Anjo da Guarda, na região da área 
Itaqui-Bacanga, zona periférica de São Luís (MA). Investigou-se o processo de surgimento do trabalho das parteiras a partir dos relatos de 18 delas e sua relação com a Secretaria Municipal de Saúde, bem como suas ações. O resultado da pesquisa apontou que o trabalho desenvolvido pelas parteiras tradicionais contribui com o processo de conscientização das gestantes para a realização do pré-natal, além de proporcionar conforto psicológico para as gestantes e parturientes, humanizando, assim, o atendimento prestado à mulher no período gravídico.

120. PEREIRA, Raquel da Rocha; FRANCO, Selma Cristina; BALDIN, Nelma. Representações sociais e decisões das gestantes sobre a parturição: protagonismo das mulheres. Saúde e Sociedade, v.20, n.3, p.579-589. 2011. Disponivel em: <http://www.scielo.br/scielo.php?script=sci_arttext\&pid=S0104-12902011000300005\&lng $=$ pt\&nrm=iso\&tlng=pt $>$. Acesso em: 30 ago. 2017.

- Analisa, a partir das representações sociais femininas, o protagonismo da mulher na decisão sobre a parturição. A análise de conteúdo dos relatos possibilitou emergirem três categorias empíricas: medos e preocupações; vivências; e influência sociocultural. Com esse substrato teórico-metodológico, analisou-se a representação social da mulher no processo da parturição, que é simbolizado por conflitos de sentimentos, dúvidas e apreensões originadas principalmente pelo medo do sofrimento imposto pela dor.

121. PINHEIRO, Bruna Cardoso; BITTAR, Cléria Maria Lôbo. Expectativas, percepções e experiências sobre o parto normal: relato de um grupo de mulheres. Fractal: Revista de Psicologia, v.25, n.3, p.585-602. 2013. Disponível em: <http://www.scielo.br/scielo.php?script=sci_arttext\&pid=S1984-02922013000300011\&lng=pt\&nrm=is o\&tlng=pt $>$. Acesso em: 13 set. 2017.

- Busca conhecer as percepções, experiências e expectativas em relação ao parto normal, além de saber qual tipo de informação as entrevistadas dispunham sobre a parturição, puerpério e o direito de ter um acompanhante no parto. As entrevistadas demonstraram maior preferência pelo parto normal. A maioria das informações ou orientações recebidas pelos profissionais de saúde restringiu-se à dimensão física da dor e primeiros cuidados com o nascituro, em detrimento da dimensão psicológica e emocional, relegando-as a uma posição passiva, o que não as impediu de serem críticas quanto às orientações recebidas.

122. PIRES, Denise; FERTONANI, Hosanna Pattrig; CONILL, Eleonor Minho; MATOS, Thaís Alves; CORDOVA, Fernanda Peixoto; MAZUR, Cíntia da Silva. A influência da assistência profissional em saúde na escolha do tipo de parto: um olhar socioantropológico na saúde suplementar brasileira. Revista Brasileira de Saúde Materno Infantil, v.10, n.2, p.191-197. 2010. Disponivel em: <http://www.scielo.br/scielo.php?script=sci_ arttext\&pid=S1519-38292010000200006\&lng=pt\&nrm=iso\&tlng=p >. Acesso em: 11 set. 2017.

- Visa contribuir para a compreensão da influência da assistência profissional na escolha do tipo de parto realizado entre usuárias do setor suplementar de saúde. Os resultados mostraram alta incidência de parto cesáreo, e entre os fatores que contribuíram para este fenômeno identificouse a medicalização do processo gravidez-parto, o medo da dor, a conveniência da data marcada e um processo de negociação/orientação que se estabelece entre a gestante e seus familiares e o profissional médico fortemente influenciado pelo vínculo de confiança dessa relação.

123. PREVIATTI, Jaqueline Fátima; SOUZA, Kleyde Ventura de. Episiotomia: em foco a visão das mulheres. Revista Brasileira de Enfermagem, v.60, n.2, p.197-201.2007. Disponível em:<http://www.scielo.br/scielo.php?script=sci_ arttext\&pid=S0034-71672007000200013\&lng=pt\&nrm=iso\&tlng=pt $>$. Acesso em: 25 ago. 2017.

- Busca identificar a visão de um grupo de puérperas em relação à episiotomia, para isso, realizouse um estudo de abordagem qualitativa, com participação de vinte mulheres, no período pós-parto. Verificou-se o desconhecimento das mulheres em relação à episiotomia e sobre seu próprio corpo e o fato de que não receberam informações em nenhum momento de que se trata de uma intervenção seletiva, indicando a necessidade de ampliação do conhecimento e do resgate da autonomia da mulher no processo de parto e nascimento. 
124. PROGIANTI, Jane Márcia; COSTA, Rafael Ferreira da. A negociação do cuidado de enfermagem obstétrica através das práticas educativas na casa de parto. Escola Anna Nery, v.12, n.4, p.790-793. 2008. Disponível em: <http://www.scielo.br/scielo.php?script=sci_arttext\&pid=S1414-81452008000400025\&lng=pt\&nrm=iso\&tl ng=pt>. Acesso em: 28 ago. 2017.

- Reflete sobre o cuidado de enfermagem obstétrica desenvolvido na Casa de Parto David Capistrano Filho. Essa reflexão, utilizando-se do conceito de negociação da teoria do cuidado cultural e do conceito de educação em saúde, respondeu por que nesse espaço, construído para o desenvolvimento de ações sob a visão do modelo humanizado, as enfermeiras obstétricas se apoiam nas práticas de educação em saúde. Concluiu-se que a educação em saúde é instrumento do cuidado cultural, e as enfermeiras, ao utilizarem as práticas educativas, estão negociando o cuidado humanizado com a mulher que está socialmente habituada com as concepções do modelo tecnocrático.

125. PROGIANTI, Jane Márcia; COSTA, Rafael Ferreira da. Práticas educativas desenvolvidas por enfermeiras: repercussões sobre vivências de mulheres na gestação e no parto. Revista Brasileira de Enfermagem, v.65, n.2, p.257-263. 2012. Disponível em: <http://www.scielo.br/scielo.php?script=sci_arttext\&pid=S0034$71672012000200009 \&$ lng=pt\&nrm=iso\&tlng=pt $>$. Acesso em: 13 set. 2017.

- Discute as repercussões das práticas educativas desenvolvidas por enfermeiras sobre a vivência das mulheres na gravidez e no parto. Estudo qualitativo realizado por meio de entrevista a mulheres que pariram e que frequentaram os grupos educativos e consultas em uma casa de parto. Os resultados mostraram que as práticas educativas foram reestruturantes para a vivência tranquila, formação do vínculo materno, livre expressão da sexualidade durante a gestação e sensações vividas no parto.

126. PROGIANTI, Jane Márcia; LOPES, Alessandréa Silva; GOMES, Raquel Cristina Pitão. A participação da enfermeira no processo de desmedicalização do parto. Revista Enfermagem UERJ, v.11, n.3, p.273-277. 2003. Disponível em: <http://www.facenf.uerj.br/v11n3/v11n3a06.pdf>. Acesso em: 17 set. 2017.

- Procura identificar as estratégias adotadas pela Secretaria Municipal de Saúde do Rio de Janeiro para desmedicalizar o parto e discutir a participação das enfermeiras nesse processo. Os resultados evidenciam que as estratégias da Secretaria Municipal de Saúde basearam-se na mudança de ambiente físico, na criação da casa de parto e na inserção da enfermeira obstétrica na assistência.

127. PROGIANTI, Jane Márcia; PORFÍRIO, Aline Bastos. Participação das enfermeiras no processo de implantação de práticas obstétricas humanizadas na maternidade Alexander Fleming (1998-2004). Escola Anna Nery, v.16, n.3, p.443-450. 2012. Disponível em: <http://www.scielo.br/scielo.php?script=sci_arttext\&pid=S1414$81452012000300003 \&$ Ing=pt\&nrm=iso\&tlng=pt>. Acesso em: 31 ago. 2017.

- Analisa o processo de inserção das enfermeiras na assistência ao parto e as lutas dessas profissionais para implantar as práticas obstétricas humanizadas na Maternidade Alexander Fleming. Os resultados apontaram que a inserção das enfermeiras na assistência ao parto ocorreu mediante a lotação de recursos humanos para esse projeto e de uma capacitação intensiva. Ao serem inseridas no centro obstétrico, as enfermeiras criaram um espaço próprio de atuação e elaboraram um protocolo assistencial.

128. PROGIANTI, Jane Márcia. Modelos de assistência ao parto e a participação feminina. Revista Brasileira de Enfermagem, v.57, n.3, p.303-305. 2004. Disponível em: <http://www.scielo.br/scielo.php?script=sci_ arttext\&pid=S0034-71672004000300009\&lng=pt\&nrm=iso\&tlng=pt>. Acesso em: 22 ago. 2017.

- Analisa quatro propostas de assistência obstétrica que coexistiram na cidade do Rio de Janeiro no início dos anos 1930 até os anos 1950, bem como discute a inserção das parteiras curiosas, das parteiras diplomadas e das enfermeiras. Trata-se de um trabalho de natureza histórico-social que utiliza documento escrito como fonte primária. Analisou-se o serviço obstétrico domiciliar do modelo sanitarista; a proposta filantrópica das damas da sociedade; a assistência hospitalar 
individualizada; e a proposta de assistência obstétrica integrada, e identificou-se um processo de exclusão das figuras femininas não médicas do campo obstétrico brasileiro.

129. RABELO, Leila Regina; OLIVEIRA, Dora Lúcia de. Percepções de enfermeiras obstétricas sobre sua competência na atenção ao parto normal hospitalar. Revista da Escola de Enfermagem da USP, v.44, n.1, p.213-220. 2010. Disponível em: <http://www.scielo.br/scielo.php?script=sci_arttext\&pid=\$0080-62342010000100030\&lng $=$ pt\&nrm=iso\&tlng=pt $>$. Acesso em: 11 set. 2017.

- Investiga a percepção de enfermeiras obstétricas sobre sua competência na atenção ao parto normal (PN) hospitalar. Os dados foram coletados em pesquisa qualitativa, por meio de entrevistas realizadas em um hospital universitário de Porto Alegre, e submetidos à análise de conteúdo. A análise foi embasada nos referenciais que definem competência profissional como a capacidade de mobilizar diferentes conhecimentos, dependendo dos problemas da prática a resolver. Para as entrevistadas, a competência para atender o PN hospitalar mostrou ser multidimensional, embora tenham enfatizado sua dimensão técnica.

130. RANGEL, Vanessa Maia; CAMARGO JR., Kenneth Rochel de. A negociação de um corpo com dor: racionalidade biomédica na dinâmica ritualizada do trabalho de parto hospitalar. Physis: Revista de Saúde Coletiva, v.26, n.4, p.1.293-1.310. 2016. Disponível em: <http://www.scielo.br/scielo.php?script=sci_arttext\&pid=S0103$73312016000401293 \& \operatorname{lng}=p t \& n r m=i s o \& t l n g=p t>$. Acesso em: 15 set. 2017.

- Analisa o status da parturiente durante o ritual do trabalho de parto hospitalar. Para isso, partiuse do entendimento da racionalidade biomédica de que o paradigma obstétrico se caracteriza pela intervenção técnica e tecnológica no corpo feminino, pela crença de sua biologia instável e pelo caráter liminar da parturiente, na expectativa do nascimento de um bebê saudável. O diálogo que se estabelece entre obstetras e parturientes considera diferentes perspectivas, atores, locais e instrumentos, estabelecendo o sofrimento corporal, pela dor do trabalho de parto, como o grande negociador da dinâmica ritual.

131. RATTNER, Daphne; MOURA, Erly Catarina de. Nascimentos no Brasil: associação do tipo de parto com variáveis temporais e sociodemográficas. Revista Brasileira de Saúde Materno Infantil, v.16, n.1, p.39-47. 2016. Disponível em: <http://www.scielo.br/scielo.php?script=sci_arttext\&pid=S1519-38292016000100039\&lng $=p t \& n r m=i s o \& t \mid n g=p t>$. Acesso em: 16 set. 2017.

- Procura descrever nascimentos via cesariana e vaginal e identificar associação com variáveis temporais e sociodemográficas. Identificou-se que a proporção de cesarianas no país aumentou cerca de $40 \%$ de 2000 para 2010. Os partos por via vaginal se distribuíram de modo similar nos diferentes dias da semana e períodos do dia, enquanto as cesarianas se concentraram nos dias úteis e nos períodos diurnos. A proporção de cesarianas foi menor no Norte, na população indígena, entre mulheres sem escolaridade e entre solteiras, apresentando tendência crescente com idade e escolaridade. Após ajuste, a Região Centro-Oeste apresentou maior probabilidade de cesarianas e as demais variáveis mantiveram a associação.

132. RATTNER, Daphne. Humanização na atenção a nascimentos e partos: breve referencial teórico. Interface Comunicação, Saúde, Educação, v.13, supl.1, p.595-602. 2009. Disponível em: <http://www.scielo.br/scielo. php?script=sci_arttext\&pid=S1414-32832009000500011\&lng=pt\&nrm=iso >. Acesso em: 29 ago. 2017.

- Apresenta um breve referencial teórico sobre o tema da humanização da atenção a nascimentos e partos. O trabalho identifica um forte movimento internacional que aborda a humanização da atenção a nascimentos e partos como uma resposta à mecanização na organização do trabalho profissional e à violência institucional, com crescente produção teórica.

133. REBELLO, Maria Tereza Maia Penido; RODRIGUES NETO, João Felício. A humanização da assistência ao parto na percepção de estudantes de medicina. Revista Brasileira de Educação Médica, v.36, n.2, p.188-197. 2012. Disponivel em: <http://www.scielo.br/scielo.php?script=sci_arttext\&pid=S0100-55022012000400006\&lng $=p t \& n r m=i s o \& t$ lng=pt $>$. Acesso em: 31 ago. 2017. 
- Apresenta um estudo de abordagem qualitativa, exploratório-descritivo, com o objetivo de verificar a concepção de parto humanizado na perspectiva de estudantes de medicina. O estudo mostrou a associação, pelos estudantes de medicina, de aspectos humanísticos aos aspectos biomédicos da assistência ao parto, confirmando o processo de mudança que vivenciamos na educação médica.

134. REIS, Adriana Elias dos; PATRÍCIO, Zuleica Maria. Aplicação das ações preconizadas pelo Ministério da Saúde para o parto humanizado em um hospital de Santa Catarina. Ciência \& Saúde Coletiva, v.10, supl.0, p.221-230. 2005. Disponível em: <http://www.scielo.br/scielo.php?script=sci_arttext\&pid=S1413$81232005000500023 \&$ lng =pt\&nrm=iso >. Acesso em: 22 ago. 2017.

- Analisa a aplicação das ações das equipes de saúde no processo de parir preconizadas pelo Ministério da Saúde em um centro obstétrico de um hospital do estado de Santa Catarina. A análise dos dados mostrou limitações da equipe de saúde para incorporar as referidas diretrizes no cotidiano da assistência, bem como das gestantes e acompanhantes em estimular essa prática, especialmente pelo desconhecimento que têm de seus direitos.

135. REIS, Thamiza; PADOIN, Stela;TOEBE, Thayla; PAULA, Cristiane Cardoso de; QUADROS, Jacqueline. Autonomia feminina no processo de parto e nascimento: revisão integrativa da literatura. Revista Gaúcha de Enfermagem, v.38, n.1, e64677. 2017. Disponível em: <http://www.scielo.br/scielo.php?script=sci_arttext\&pid=S198314472017000100503\&lng=pt\&nrm=iso\&tlng=pt>. Acesso em: 16 set. 2017.

- Procura identificar as evidências disponíveis na produção científica acerca das práticas de assistência à saúde que interferem no exercício da autonomia das mulheres brasileiras no processo de parto e nascimento. A busca dos artigos foi desenvolvida nas bases de dados Lilacs, Scopus e PubMed, no período entre 1996 e 2015, sendo selecionados 22 artigos. Foram evidenciadas como práticas que favorecem o exercício da autonomia feminina: práticas assistenciais extra-hospitalares; práticas assistenciais de apoio e conforto; e práticas assistenciais educativas. Em contrapartida, revelaram-se como práticas limitantes ao exercício da autonomia: práticas assistenciais autoritárias; práticas assistenciais padronizadas ou rotineiras; práticas assistenciais que intensificam a sensação dolorosa do parto; e prática assistencial impessoal e fria. Os resultados encontrados valorizam a necessidade de maior intervenção da enfermagem em prol da autonomia das mulheres, propiciando um resgate do seu protagonismo no processo de parto e nascimento.

136. RIESCO, Maria Luiza Gonzalez; FONSECA, Rosa Maria Godoy Serpa da. Elementos constitutivos da formação e inserção de profissionais não médicos na assistência ao parto. Cadernos de Saúde Pública, v.18, n.3, p.685698. 2002. Disponível em: <http://www.scielo.br/scielo.php?script=sci_arttext\&pid=S0102-311X200200030 0012\&lng=pt\&nrm=iso\&tlng=pt>. Acesso em: 4 set. 2017.

- Procura identificar a parteira, segundo a concepção de profissionais da área de saúde, e desvelar os pressupostos ideológicos que justificam sua formação. Os dados de entrevistas com nove obstetrizes, enfermeiras e médicos foram tratados pela análise de discurso, resultando nas categorias empíricas "Situação da assistência ao parto no Brasil" e "A parteira que queremos (ou devemos) e a parteira que podemos".

137. RIESCO, Maria Luiza Gonzalez; OLIVEIRA, Sonia Maria Junqueira Vasconcellos de; BONADIO, Isabel Cristina; SCHNECK, Camilla Alexsandra; SILVA, Flora Maria Barbosa da; DINIZ, Carmen Simone Grilo; LOBO, Sheila Fagundes; SAITO, Emilia. Centros de parto no Brasil: revisão da produção científica. Revista da Escola de Enfermagem da USP, v.43, n.spe.2, p.1.297-1.302. 2009. Disponível em: <http://www.scielo.br/scielo.php?script=sci_ arttext\&pid=S0080-62342009000600026\&lng=pt\&nrm=iso\&tlng=pt>. Acesso em: 10 set. 2017.

- Apresenta uma revisão narrativa com o objetivo de identificar a produção científica brasileira relacionada ao processo assistencial e aos resultados maternos e perinatais em centro de parto normal (CPN). As publicações foram recuperadas nas bases de dados e portais de periódicos 
PubMed/Medline, Cinahal, Scielo e Revenf. Incluíram-se, também, publicação em livro e produção não publicada de grupo de pesquisa. Os estudos analisaram variáveis sociodemográficas e obstétricas, práticas na assistência ao parto e nascimento e remoções maternas e neonatais para o hospital.

138. RIESCO, Maria Luiza Gonzalez; TSUNECHIRO, Maria Alice; MOTT, Maria Lucia; LEISTER, Nathalie. Do orgulho à resignação: educação e atuação profissional de obstetrizes formadas pela Universidade de São Paulo. Cadernos de História da Ciência, v.7, n.2, p.9-24. 2011. Disponível em: <http://periodicos.ses.sp.bvs.br/scielo. php?script=sci_arttext\&pid=S1809-76342011000200002\&lng=pt\&nrm=iso >. Acesso em: 16 set. 2017.

- Descreve e analisa a educação e atuação profissional de obstetrizes formadas pela Universidade de São Paulo até 1970. As relações entre alunas, professores e profissionais refletem a hierarquia estabelecida nos serviços de saúde. As obstetrizes atuaram principalmente na assistência à mulher no parto, em serviços privados, filantrópicos e da rede pública, incluindo o Serviço Obstétrico Domiciliar. A partir dos anos de 1970, elas sofreram um processo de exclusão da assistência ao parto, sendo substituídas por médicos.

139. RISCADO, Liana Carvalho; JANNOTTI, Claudia Bonan; BARBOSA, Regina Helena Simões. A decisão pela via de parto no Brasil: temas e tendências na produção da saúde coletiva. Texto \& Contexto - Enfermagem, v.25, n.1. 2016. Disponível em: <http://www.scielo.br/scielo.php?script=sci_arttext\&pid=S0104$07072016000100501 \&|n g=p t \& n r m=i s o \& t| n g=p t>$. Acesso em: 16 set. 2017.

- Estuda a produção de conhecimento no campo da saúde coletiva sobre a "decisão" relacionada à via de parto. Trata-se de um estudo de revisão integrativa da literatura que discute usos, potencialidades e limites dessa categoria nas análises sobre a prática da cesariana no Brasil. Utilizou-se uma combinação de técnicas de análise temática e de discurso. Considera-se que a literatura sobre cesariana no Brasil tem avançado ao sair do foco estreito de escolha individual para uma contextualização mais profunda. Acredita-se, porém, que a literatura ainda precisa progredir, pois há poucas discussões de questões socioculturais, políticas, econômicas e sobre o papel das tecnologias médicas e não médicas.

140. ROCHA, Semíramis Melani Melo; SIMPIONATO, Érica; MELLO, Débora Falleiros de. Apego mãe-filho: estudo comparativo entre mães de parto normal e cesárea. RevistaBrasileira de Enfermagem, v.56, n.2, p.125-129. 2003. Disponível em: <http://www.scielo.br/scielo.php?script=sci_arttext\&pid=S0034-71672003000200002\&lng $=$ pt\&nrm=iso\&tlng=pt $>$. Acesso em: 5 set. 2017.

- Compara o comportamento de mães e recém-nascidos de parto normal e de parto cesárea, nas primeiras 24 horas de vida, em alojamento conjunto neonatal. Foram observados 14 binômios mãe-filho, sendo sete bebês nascidos de parto normal e sete de cesárea. As observações permitiram conclusões úteis para o cuidado de enfermagem, e também como o ambiente pode influir no estabelecimento de vínculos bem sucedidos entre mãe-filho.

141. ROCHA, Tatiana Augustinho; BONILHA, Ana Lúcia de Lourenzi. Formação das enfermeiras para a parturição: implantação de um hospital universitário na década de 80. Escola Anna Nery, v.12, n.4, p.651-657. 2008. Disponivel em: <http://www.scielo.br/scielo.php?script=sci_arttext\&pid=\$1414-81452008000400007\&lng $=p t \& n r m=i s o \& t$ lng=pt $>$. Acesso em: 28 ago. 2017.

- Busca conhecer o contexto político e de ensino que nortearam a formação de enfermeiras gaúchas na área obstétrica e como isso se deu nos primeiros anos de funcionamento de uma maternidade em hospital universitário de Porto Alegre (RS). A análise e discussão focalizaram-se nas políticas de saúde no período, na formação e nas práticas das enfermeiras para o partejar.

142. RODRIGUES, Ana Verônica; SIQUEIRA, Arnaldo A. Franco de. Sobre as dores e temores do parto: dimensões de uma escuta. Revista Brasileira de Saúde Materno Infantil, v.8, n.2, p.179-186. 2008. Disponível em: <http:// www.scielo.br/scielo.php?script=sci_arttext\&pid=\$1519-38292008000200005\&lng=pt\&nrm=iso\&tlng= pt>. Acesso em: 8 set. 2017. 
- Procura desenvolver algumas reflexões sobre os possíveis efeitos benéficos de uma escuta responsiva à verbalização da presença de dor, medos e seus correlatos na cena do parto, tomando como base dados empíricos de pesquisa realizada em maternidade situada na cidade de São Paulo. A análise, apoiada em categorias estabelecidas, mostrou, entre outros pontos, a importância e a valorização da interlocução qualificada no processo da parturição. Processo esse referido pelas parturientes como experiência de elevado grau de estresse, com vivências de dor, medos e ansiedades, porém mitigados pelo apoio recebido.

143. SAKAE, Thiago Mamôru; FREITAS, Paulo Fontoura; D'ORSI, Eleonora. Fatores associados a taxas de cesárea em hospital universitário. Revista de Saúde Pública, v.43, n.3, p.472-480. 2009. Disponível em: <http://www.scielo. $\mathrm{br} / \mathrm{scielo}$.php?script=sci_arttext\&pid=S0034-89102009000300011\&lng=pt\&nrm=iso\&tlng=pt $>$. Acesso em: 10 set. 2017.

- Analisa fatores associados à realização do parto cesariano. Estudo transversal realizado em hospital universitário de Florianópolis (SC), de 2001 a 2005. Foram analisados fatores socioeconômicos, de experiências reprodutivas, institucionais e relacionados à prática obstétrica. As informações relativas a 7.249 partos foram obtidas a partir de prontuários clínicos e registros de admissão, parto e pós-parto. As taxas de cesárea aumentaram de $27,5 \%$ a 36,5\% no período e estiveram acima daquelas devidas a indicações médicas.

144. SANFELICE, Clara Fróes de Oliveira; SHIMO, Antonieta Keiko Kakuda. Parto domiciliar: avanço ou retrocesso? Revista Gaúcha de Enfermagem, v.35, n.1, p.157-160. 2014. Disponivel em: <http://www.scielo.br/scielo. php?script=sci_arttext\&pid=S1983-14472014000100157\&lng=pt\&nrm=iso\&tlng=pt $>$. Acesso em: 14 set. 2017. - Apresenta um panorama global da assistência ao parto domiciliar, problematizando a realidade do cenário obstétrico brasileiro contemporâneo. A literatura científica apresenta resultados obstétricos e neonatais favoráveis ao parto domiciliar, risco semelhante quando comparado ao parto hospitalar e maiores índices de satisfação materna, fatores que legitimam a sua prática. Assim, observa-se, na atualidade, um movimento de mulheres que, profundamente descontentes com o modelo de atenção obstétrica vigente, têm optado pelo parto em casa como reação à violência institucional, à fragmentação e despersonalização da assistência hospitalar.

145. SANFELICE, Clara Fróes de Oliveira; SHIMO, Antonieta Keiko Kakuda. Representações sociais sobre o parto domiciliar. Escola Anna Nery, v.19, n.4, p.606-613. 2015. Disponível em: <http://www.scielo.br/scielo. php?script=sci_arttext\&pid=\$1414-81452015000400606\&lng=pt\&nrm=iso\&tlng=pt $>$. Acesso em: 15 set. 2017.

- Procura conhecer as representações sociais sobre o parto domiciliar de mulheres que fizeram essa opção diante da escassez de estudos que avaliem esse fenômeno sob uma perspectiva humana, histórica e social. Trata-se de uma pesquisa qualitativa, exploratória e descritiva, fundamentada na teoria das representações sociais. Foram entrevistadas 14 mulheres que vivenciaram ao menos uma experiência de parto domiciliar, assistido e planejado, na cidade de Campinas (SP) e região entre fevereiro e março de 2014. Utilizou-se o critério de saturação teórica para definição do tamanho amostral. As reflexões apresentadas servem como subsídios para debate e reformulação das políticas de saúde obstétrica brasileira.

146. SANFELICE, Clara Fróes de Oliveira; SHIMO, Antonieta Keiko Kakuda. Parto domiciliar: compreendendo os motivos dessa escolha. Texto \& Contexto - Enfermagem, v.24, n.3, p.875-882. 2015. Disponível em: <http:// www.scielo.br/scielo.php?script=sci_arttext\&pid=S0104-07072015000300875\&lng=pt\&nrm=iso\&tlng= pt>. Acesso em: 15 set. 2017.

- Busca compreender os motivos que sustentam a escolha pelo parto domiciliar. As informações foram captadas por meio de entrevistas semiestruturadas, aplicadas entre fevereiro e março de 2014 , gravadas e transcritas. A amostra, obtida por meio de saturação de dados, foi composta por 14 mulheres que tinham pelo menos uma experiência de parto em casa, planejado e assistido, 
no último ano, na cidade de Campinas (SP) e região. As falas foram analisadas segundo o método de análise de conteúdo. Os resultados originaram duas categorias. Os motivos elencados evidenciam que a aquisição do conhecimento é condição básica para respaldar a decisão de parir em casa, além de revelar uma grande insatisfação dessas mulheres com o atual modelo institucionalizado de atenção ao parto.

147. SANTOS, Denise da Silva; NUNES, Isa Maria. Doulas na assistência ao parto: concepção de profissionais de enfermagem. Escola Anna Nery, v.13, n.3, p.582-588. 2009. Disponível em: <http://www.scielo.br/scielo. php?script=sci_arttext\&pid=S1414-81452009000300018\&lng=pt\&nrm=iso\&tlng=pt $>$. Acesso em: 10 set. 2017. - Procura descrever a concepção das profissionais de enfermagem sobre a participação das doulas na assistência à mulher no trabalho de parto. Os sujeitos foram 11 auxiliares/técnicas de enfermagem e cinco enfermeiras(os) atuantes no centro obstétrico de uma maternidade pública em Salvador (BA). Constatou-se que essa iniciativa objetivou preencher a lacuna do acompanhante no centro obstétrico da instituição. Dentre as facilidades identificadas, têm relevância a substituição da família e o conforto físico proporcionado à mulher, e, como dificuldades, observam-se a indefinição do papel e a falta de clareza no limite de atuação das doulas.

148. SANTOS, Flávia; ENDERS, Bertha Cruz; SANTOS, Viviane; DANTAS, Dândara; MIRANDA, Larissa. Integralidade e atenção obstétrica no Sistema Único de Saúde: reflexão à luz da teoria da complexidade de Edgar Morin. Escola Anna Nery, v.20, n.4, e20160094. 2016. Disponível em: <http://www.scielo.br/scielo.php?script=sci_ arttext\&pid=S1414-81452016000400602\&lng=pt\&nrm=iso\&tlng=pt>. Acesso em: 16 set. 2017.

- Visa refletir sobre a integralidade e a atenção obstétrica no Sistema Único de Saúde à luz da teoria da complexidade de Edgar Morin. Identificou-se que a institucionalização e a hegemonia do modelo cartesiano levaram à segmentação do ser humano e à fragmentação do cuidado e interferiram no alcance da integralidade da atenção obstétrica no Sistema Único de Saúde.

149. SANTOS, Jaqueline de Oliveira; SHIMO, Antonieta Keiko Kakuda. Prática rotineira da episiotomia refletindo a desigualdade de poder entre profissionais de saúde e mulheres. Escola Anna Nery, v.12, n.4, p.645-650. 2008. Disponível em: <http://www.scielo.br/scielo.php?script=sci_arttext\&pid=S1414-81452008000400006\&lng $=$ pt\&nrm=iso\&tlng=pt>. Acesso em: 25 ago. 2017.

- Visa identificar o conhecimento e a participação das mulheres nas decisões obstétricas, por meio de um estudo qualitativo com mulheres submetidas à episiotomia durante o parto em um hospital escola no interior de Minas Gerais. Da análise das entrevistas, evidenciou-se que as mulheres apresentam déficit de conhecimento relacionado à intervenção. A observação demonstrou que a episiotomia foi realizada sem informação e sem autorização prévia das participantes do estudo, revelando a relação de autoridade exercida pelos profissionais durante a assistência ao parto.

150. SANTOS, Luciano Marques; PEREIRA, Samantha. Vivências de mulheres sobre a assistência recebida no processo parturitivo. Physis: Revista de Saúde Coletiva, v.22, n.1, p.77-97. 2012. Disponível em: <http://www. scielo.br/scielo.php?script=sci_arttext\&pid=S0103-73312012000100005\&lng=pt\&nrm=iso\&tlng=pt > . Acesso em: 13 set. 2017.

- Procura compreender as vivências de puérperas sobre a atenção recebida durante o processo parturitivo em uma maternidade pública de Feira de Santana (BA). A análise de conteúdo e semiológica dos dados demonstrou que as entrevistadas vivenciaram o processo parturitivo com solidão, medo, dor, sofrimento e abandono, e tiveram seus filhos sozinhas. Os únicos momentos de assistência foram limitados ao período expulsivo ou do pós-parto.

151. SCHREINER, Margareth; COSTA, Juvenal Soares Dias da; OLINTO, Maria Teresa Anselmo; MEMEGHEL, Stela Nazareth. Assistência ao parto em São Leopoldo (RS): um estudo de base populacional. Ciência \& Saúde Coletiva, v.15, n.supl.1, p.1.411-1.416. 2010. Disponivel em: <http://www.scielo.br/scielo.php?script=sci_ arttext\&pid=S1413-81232010000700051\&lng=pt\&nrm=iso\&tlng=pt>. Acesso em: 11 set. 2017. 
- Descreve as condições estruturais de assistência ao parto na cidade de São Leopoldo (RS), estabelece o percentual de cesarianas, as características de atenção ao parto e verifica a associação do tipo e presença de pediatra no parto com variáveis socioeconômicas. Foram encontradas evidências mostrando a associação de tipo de parto e variáveis que expressam classe econômica, sendo possível afirmar que a remuneração interfere no tipo de parto.

152. SEIBERT, Sabrina Lins; GOMES, Maysa Luduvice; VARGENS, Octavio Muniz da Costa. Assistência pré-natal da casa de parto do Rio de Janeiro: a visão de suas usuárias. Escola Anna Nery, v.12, n.4, p.758-764. 2008. Disponível em: <http://www.scielo.br/scielo.php?script=sci_arttext\&pid=\$1414-81452008000400021\&lng $=$ pt\&nrm=iso\&tlng=pt $>$. Acesso em: 28 ago. 2017.

- Analisa a assistência pré-natal oferecida pela Casa de Parto David Capistrano Filho (RJ) sob a ótica de suas usuárias e baseada no conceito de humanização do parto e nascimento. Foram convidadas a responder o questionário todas as puérperas que tiveram seus partos entre os meses de maio e setembro de 2005 . Os resultados obtidos nos informam que essa maneira diferenciada de assistência vem sendo bem aceita pela população assistida.

153. SENA, Ligia Moreiras; TESSER, Charles Dalcanale. Violência obstétrica no Brasil e o ciberativismo de mulheres mães: relato de duas experiências. Interface - Comunicação, Saúde, Educação, v.21, n.60, p.209-220. 2017. Disponivel em: <http://www.scielo.br/scielo.php?script=sci_arttext\&pid=S1414-32832017000100209\&lng $=p t \& n r m=i s o \& t \operatorname{lng}=p t>$. Acesso em: 16 set. 2017.

- Relata duas iniciativas desenvolvidas em ambiente de conectividade, utilizando as novas mídias como ferramenta: o teste da violência obstétrica e o videodocumentário "Violência obstétrica - a voz das brasileiras". As ações contribuíram para dar voz ativa às mulheres no combate à violência obstétrica, mostraram que as novas tecnologias de informação constituem importantes ferramentas de promoção da saúde da mulher e atestaram o grande potencial da internet para evidenciar violências antes pouco problematizadas, incentivando a realização de novas pesquisas na área.

154. SERRUYA, Suzanne Jacob; LAGO, Tânia Di Giácomo; CECATTI, José Guilherme. O panorama da atenção pré-natal no Brasil e o Programa de Humanização do Pré-natal e Nascimento. Revista Brasileira de Saúde Materno Infantil, v.4, n.3, p.269-279. 2004. Disponível em: <http://www.scielo.br/scielo.php?script=sci_ arttext\&pid=S1519-38292004000300007\&lng=pt\&nrm=iso\&tlng=pt $>$. Acesso em: 6 set. 2017.

- Procura contextualizar historicamente a implantação do Programa de Humanização do Pré-Natal e Nascimento do Ministério da Saúde no Brasil, resgatando, por meio de análise documental e situacional, seus aspectos conceituais, filosófico e operacional. O artigo apresenta o panorama da assistência pré-natal no Brasil no fim da década de 1990, discute os princípios da humanização como requisito para a qualidade da atenção, reconstitui o delineamento e lançamento do programa, bem como comenta aspectos práticos de sua avaliação inicial e desafios para o futuro.

155. SILVA, Ana Lucia Andrade da; MENDES, Antonio da Cruz Gouveia; MIRANDA, Gabriella Morais Duarte; SANTOS NETO, Pedro Miguel dos. Assistência ao parto no Brasil: uma situação crítica ainda não superada. 1999-2013. Revista Brasileira de Saúde Materno Infantil, v.16, n.2, p.129-137. 2016. Disponível em: <http:// www.scielo.br/scielo.php?script=sci_arttext\&pid=\$1519-38292016000200129\&lng=pt\&nrm=iso\&tlng= pt>. Acesso em: 16 set. 2017.

- Analisa a evolução da assistência ao parto no Brasil entre 1999-2013. Percebeu-se redução da fecundidade, natalidade e número total de partos. Houve crescimento dos leitos em UTI adulto e redução dos leitos de obstetrícia. Identificou-se aumento dos nascimentos entre mulheres com 40 anos e mais, com crescimento maior de $100 \%$ de primíparas nesse grupo etário, e $19 \%$ de nascimentos de mães adolescentes. O expressivo crescimento dos partos cesarianos, da cobertura de consultas pré-natal e hospitalização dos partos ocorreram simultaneamente com o crescimento: dos óbitos infantis preveníveis por adequada atenção na gestão e parto; da 
prematuridade; do baixo peso; da síndrome de Down; e da persistência das mortes maternas por causas obstétricas diretas.

156. SILVA, Andréa Lorena Santos; NASCIMENTO, Enilda Rosendo do; COELHO, Edméia de Almeida Cardoso. Práticas de enfermeiras para promoção da dignificação, participação e autonomia de mulheres no parto normal. Escola Anna Nery, v.19, n.3, p.424-431. 2015. Disponível em: <http://www.scielo.br/scielo. php? script=sci_arttext\&pid=S1414-81452015000300424\&lng=pt\&nrm=iso\&tlng=pt $>$. Acesso em: 15 set. 2017.

- Procura conhecer as práticas de cuidado utilizadas por enfermeiras implicadas nos processos de autonomia, dignificação e participação de mulheres durante o parto normal. Pesquisa qualitativa, desenvolvida com trinta mulheres que deram à luz em um centro de parto normal de Salvador (BA). Para o processo de autonomia destacaram-se a promoção de relações pessoais livres de coerção e a facilitação no acesso às informações, não deixando de estimular a participação ativa das parturientes.

157. SILVA, Larissa Mandarano da; BARBIERI, Márcia; FUSTINONI, Suzete Maria. Vivenciando a experiência da parturição em um modelo assistencial humanizado. Revista Brasileira de Enfermagem, v.64, n.1, p.60-65. 2011. Disponível em: <http://www.scielo.br/scielo.php?script=sci_arttext\&pid=\$0034-71672011000100009\&lng $=p t \& n r m=i s o \& t \operatorname{lng}=p t>$. Acesso em: 12 set. 2017.

- Procura compreender as experiências de puérperas que vivenciaram o trabalho de parto e o parto em um modelo assistencial humanizado. Os dados foram coletados em um hospital localizado na cidade de São Paulo, onde foram entrevistadas oito puérperas. Os relatos evidenciaram sentimentos como dor, medo e ansiedade, porém, possibilitou a participação e resgate da autonomia. Embora o estudo tenha sido realizado em um modelo assistencial considerado humanizado, as experiências das puérperas revelam que ainda se distanciam de uma efetiva humanização.

158. SILVA, Laura Johanson da; SILVA, Leila Rangel da; CHRISTOFFEL, Marialda Moreira. Tecnologia e humanização na Unidade de Terapia Intensiva Neonatal: reflexões no contexto do processo saúde-doença. Revista da Escola de Enfermagem da USP, v.43, n.3, p.684-689. 2009. Disponível em: <http://www.scielo.br/scielo.php?script=sci_ arttext\&pid=S0080-62342009000300026\&lng=pt\&nrm=iso\&tlng=pt >. Acesso em: 10 set. 2017.

- Apresenta reflexão acerca da tecnologia e da humanização do cuidado ao recém-nascido, tendo como preceito teórico o processo saúde-doença. São estabelecidos alguns paralelos entre as concepções de saúde e de doença, e suas influências em nosso modelo de agir e pensar nos espaços da assistência, como sujeitos do cuidado neonatal.

159. SILVA, Leila Rangel da; CHRISTOFFEL, Marialda Moreira; SOUZA, Kleyde Ventura de. História, conquistas e perspectivas no cuidado à mulher e à criança. Texto \& Contexto - Enfermagem, v.14, n.4, p.585-593. 2005. Disponível em: <http://www.scielo.br/scielo.php?script=sci_arttext\&pid=S0104-07072005000400016\&lng $=p t \& n r m=i s o \& t \mid n g=p t>$. Acesso em: 22 ago. 2017.

- Procura refletir a partir da década de 1980 até o primeiro quinquênio do século XXI sobre as conquistas e as perspectivas em termos de políticas públicas e sociais que aconteceram no campo da obstetrícia e da neonatologia no Brasil e discuti-las à luz da perspectiva do cuidado humano.

160. SILVA, Marques de Oliveira e; LOPES, Regina Lúcia Mendonça; DINIZ, Normélia Maria Freire. Vivência do parto normal em adolescentes. Revista Brasileira de Enfermagem, v.57, n.5, p.596-600. 2004. Disponível em: $<$ http://www.scielo.br/scielo.php?script=sci_arttext\&pid=\$0034-71672004000500016\&lng=pt\&nrm=iso\&tl $\mathrm{ng}=\mathrm{pt}>$. Acesso em: 5 set. 2017.

- Estudo qualitativo, construído a partir de experiências docentes e assistenciais. O objetivo do estudo é compreender a vivência da adolescente primípara com o parto normal, por meio do método fenomenológico. Conclui-se que, no cotidiano da assistência, os profissionais não estão sensíveis à compreensão da vivência singular do parto normal de cada parturiente. 
161. SILVA, Raimunda Magalhães da; BARROS, Nelson Filice de; JORGE, Herla Maria Furtado; MELO, Laura Pinto Torres de; FERREIRA JUNIOR, Antonio Rodrigues. Evidências qualitativas sobre o acompanhamento por doulas no trabalho de parto e no parto. Ciência \& Saúde Coletiva, v.17, n.10, p.2.783-2.794. 2012. Disponível em: <http://www.scielo.br/scielo.php?script=sci_arttext\&pid=S1413-81232012001000026\&lng=pt\&nrm=is o\&tlng=pt>. Acesso em: 13 set. 2017.

- Elabora uma metassíntese com as evidências sobre o trabalho das doulas no acompanhamento às mulheres em trabalho de parto e no parto. Realizou-se um levantamento nas bases de dados Medline, PubMed, Scielo, Lilacs, usando os descritores doulas, gestação, trabalho de parto, parto e terapia alternativa, no período de 2000 a 2009 . Foram selecionados sete artigos e destes emergiram quatro categorias: suporte proporcionado por doulas; experiências das parturientes; relacionamento profissional; e opiniões e experiências dos profissionais. Os principais suportes estavam relacionados aos aspectos físico, emocional, espiritual e social. As experiências evidenciaram que as doulas estimulam a relação mãe e filho, orientam para uma amamentação bem-sucedida e contribuem para prevenir a depressão pós-parto. Concluiu-se que os estudos qualitativos sobre esse tema são recentes, incipientes, mas reveladores de uma importante possibilidade para a humanização do trabalho de parto e do parto.

162. SILVA, Renata Cunha da; SOARES, Marilu Correa; JARDIM, Vanda Maria da Rosa; KERBER, Nalú Pereira da Costa; MEINCKE, Sonia Maria Könzgen. O discurso e a prática do parto humanizado de adolescentes. Texto \& Contexto - Enfermagem, v.22, n.3, p.629-636. 2013. Disponível em: <http://www.scielo.br/scielo. php?script=sci_arttext\&pid=S0104-07072013000300008\&lng=pt\&nrm=iso\&tlng=pt $>$. Acesso em: 14 set. 2017.

- Busca conhecer as práticas de atenção ao parto desenvolvidas pelos profissionais de saúde no cuidado à parturiente adolescente. Os dados foram extraídos da pesquisa Atenção Humanizada ao Parto de Adolescentes, referente ao município de Pelotas (RS), por meio de entrevistas semiestruturadas, no período de 2008 a 2009. A população constituiu-se de profissionais de saúde do centro obstétrico de um hospital de ensino público. A análise foi sistematizada a partir do Manual de Assistência ao Parto Normal, da Organização Mundial de Saúde. Concluiuse que as práticas de atenção ao parto contemplaram parcialmente a política de humanização do parto e nascimento.

163. SILVA, Tânia Maria de Almeida; FERREIRA, Luiz Otávio. A higienização das parteiras curiosas: o Serviço Especial de Saúde Pública e a assistência materno-infantil (1940-1960). História, Ciências, Saúde-Manguinhos, v.18, supl.1, p.95-112. 2011. Disponível em:<http://www.scielo.br/scielo.php?script=sci_arttext\&pid=S0104$59702011000500006 \&$ lng=pt\&nrm=iso $>$. Acesso em: 16 set. 2017.

- Discute as ações de treinamento e controle das parteiras curiosas promovidas pelo Serviço Especial de Saúde Pública, confiadas aos programas de higiene pré-natal e da criança, implantados entre as décadas de 1940 e 1960. Para os sanitaristas, o treinamento e controle das parteiras curiosas atuantes nas comunidades rurais brasileiras eram importantes para o sucesso do projeto de implantação de serviços sanitários locais de assistência materno-infantil.

164. SILVEIRA, Sandra Cristina da; CAMARGO, Brígido Vizeu; CREPALDI, Maria Aparecida. Assistência ao parto na maternidade: representações sociais de mulheres assistidas e profissionais de saúde. Psicologia: Reflexão e Crítica, v.23, n.1, p.1-10. 2010. Disponível em: <http://www.scielo.br/scielo.php?script=sci_ arttext\&pid=S0102-79722010000100002\&lng=pt\&nrm=iso\&tlng=pt>. Acesso em: 11 set. 2017.

- Investiga representações sociais de vinte mulheres assistidas e vinte profissionais de saúde sobre a assistência ao parto em maternidades. Foram realizadas quarenta entrevistas que examinaram duas maternidades com enfoques diferentes de assistência ao parto. Entre os profissionais encontraram-se duas representações distintas: a primeira denota uma visão medicalizada da assistência, e a outra aponta para uma assistência identificada com a proposta do Movimento pela Humanização do Parto e Nascimento. 
165. SIMÕES, Sonia Mara Faria. Parto e nascimento: uma compreensão das possibilidades de inserção da enfermeira. Revista Brasileira de Enfermagem, v.56, n.3, p.265-270. 2003. Disponível em: <http://www.scielo.br/scielo. php?script=sci_arttext\&pid=S0034-71672003000300010\&lng=pt\&nrm=iso\&tlng=pt>. Acesso em: 5 set. 2017. - Procura compreender a inserção da enfermeira no cenário das propostas e políticas públicas de assistência ao parto e nascimento. De natureza qualitativa, abordagem fenomenológica, utilizou como fontes documentos oficiais, periódicos de enfermagem, livros e jornais. A hermenêutica revelou que o acontecer da enfermeira ocorreu como ocupação caracterizada por ações repetidas voltadas para redução de índices de morbimortalidade maternoinfantil.

166. SODRÉ, Thelma Malagutti; BONADIO, Isabel Cristina; JESUS, Maria Cristina Pinto de; MERIGHI, Miriam Aparecida Barbosa. Necessidade de cuidado e desejo de participação no parto de gestantes residentes em Londrina-Paraná. Texto \& Contexto - Enfermagem, v.19, n.3, p.452-460. 2010. Disponível em: <http://www. scielo.br/scielo.php?script=sci_arttext\&pid=S0104-07072010000300006\&lng=pt\&nrm=iso\&tlng=pt>. Acesso em: 11 set. 2017.

- Busca compreender a necessidade de cuidado e o desejo de participação nas decisões sobre o parto de gestantes de Londrina (PR). Os resultados evidenciaram que, apesar de desejarem participar do seu parto e de verbalizarem suas necessidades, escolhas e preferências, as mulheres não encontram condições favoráveis para que tais necessidades e desejo de participação sejam viabilizados; fato que interfere nas relações face a face e impede o direito à escolha informada em relação ao parto.

167. SOUSA, Ana Maria Magalhães; SOUZA, Kleyde Ventura de; REZENDE, Edna Maria; MARTINS, Eunice Francisca; CAMPOS, Deise; LANSKY, Sônia. Práticas na assistência ao parto em maternidades com inserção de enfermeiras obstétricas, em Belo Horizonte, Minas Gerais. Escola Anna Nery, v.20, n.2, p.324-331. 2016. Disponível em: <http://www.scielo.br/scielo.php?script=sci_arttext\&pid=S1414-81452016000200324\&lng $=p t \& n r m=i s o \& t$ lng $=p t>$. Acesso em: 16 set. 2017.

- Discute práticas na assistência ao parto em instituições de saúde onde atuam conjuntamente médicos e enfermeiras obstétricas. Estudo transversal que teve como fonte de dados a pesquisa Nascer em Belo Horizonte: um inquérito sobre parto e nascimento, realizada entre 2011 e 2013. Concluiu-se que mesmo em instituições que se empenham na mudança do modelo de atenção obstétrica foram identificadas práticas que reproduzem o modelo tecnocrático.

168. SOUZA, Karla Romana Ferreira de; DIAS, Maria Djair. História oral: a experiência das doulas no cuidado à mulher. Acta Paulista de Enfermagem, v.23, n.4, p.493-499. 2010. Disponível em: <http://www.scielo.br/scielo. php?script=sci_arttext\&pid=S0103-21002010000400008\&lng=pt\&nrm=iso\&tlng=pt>. Acesso em: 11 set. 2017. - Estudo qualitativo realizado em uma maternidade pública municipal na cidade do Recife (PE) com o objetivo de compreender o significado da experiência das doulas durante o processo de parto e nascimento. O instrumento de investigação utilizado foi a entrevista. Emergiram dois eixos temáticos que trazem a experiência das doulas no cuidado à mulher. Os discursos revelaram que as doulas oferecem um cuidado que envolve uma escuta ativa, alicerçada em atitudes de respeito, acolhimento, conhecimento técnico e amor.

169. SOUZA, Silvana Regina Rossi Kissula; GUALDA, Dulce Maria Rosa. A Experiência da mulher e de seu acompanhante no parto em uma maternidade pública. Texto \& Contexto-Enfermagem, v.25, n.1, elocation e4080014. 2016. Disponível em: <http://www.scielo.br/scielo.php?script=sci_arttext\&pid=S010407072016000100309\&lng=pt\&nrm=iso\&tlng=pt>. Acesso em: 16 set. 2017.

- Estudo qualitativo que se utiliza da história oral temática com objetivo de conhecer a experiência de mulheres e de seus acompanhantes no processo de parto, realizado em uma maternidade pública do Paraná entre outubro de 2012 e maio de 2013 com 11 mulheres e 11 acompanhantes. Os dados foram coletados por meio de entrevistas semiestruturadas, gravadas, transcritas, retextualizadas e analisadas tematicamente. Concluiu-se que a participação do acompanhante 
no modelo de assistência ao parto vigente apresenta avanços, contudo, encontra barreiras para que se realize plenamente no modelo do parto humanizado.

170. SOUZA, Taísa Guimarães de; GAÍvA, Maria Aparecida Munhoz; MODES, Priscilla Shirley Siniak dos Anjos. A humanização do nascimento: percepção dos profissionais de saúde que atuam na atenção ao parto. Revista Gaúcha de Enfermagem, v.32, n.3, p.479-486. 2011. Disponível em: <http://www.scielo.br/scielo.php?script=sci_ arttext\&pid=S1983-14472011000300007\&lng=pt\&nrm=iso\&tlng=pt>. Acesso em: 30 ago. 2017.

- Busca conhecer a percepção dos profissionais de saúde que atuam na assistência ao parto sobre a humanização do processo de nascimento. Os resultados mostram que a humanização na assistência ao nascimento ainda não é uma prática presente na maioria dos hospitais estudados e que os profissionais não estão preparados para prestar um atendimento humanizado e com qualidade tanto para a mãe quanto para o recém-nascido.

171. TARNOWSKI, Karina da Silva; PRÓSPERO, Elisete Navas Sanches; ELSEN, Ingrid. A participação paterna no processo de humanização do nascimento: uma questão a ser repensada. Texto \& Contexto-Enfermagem, v.14, n.spe, p.102-108. 2005. Disponível em: <http://www.scielo.br/scielo.php?script=sci_arttext\&pid=S0104$07072005000500013 \&$ lng=pt\&nrm=iso\&tlng=pt $>$. Acesso em: 23 ago. 2017.

- Promove reflexão acerca do processo da participação paterna no momento do parto. A contemporaneidade oferece uma pluralidade de sistemas de significação e cada pessoa precisa construir sua forma de ser no mundo. Nessa perspectiva, é fundamental buscar os significados circulantes e suas contradições, rupturas com antigas significações, relações com discursos de diferentes ordens, enfim, colocar a paternidade como questão cultural. Apesar do empenho na humanização da assistência no período gravídico-puerperal, observa-se que pouco se avançou quanto à participação do pai na arena da saúde reprodutiva.

172. THÉBAUD, Françoise. A medicalização do parto e suas consequências: o exemplo da França no período entre as duas guerras. Revista Estudos Feministas, v.10, n.2, p.415-426. 2002. Disponível em: <http://www.scielo.br/ scielo.php?script=sci_arttext\&pid=S0104-026X2002000200011\&lng=pt\&nrm=iso\&tlng=pt $>$. Acesso em: 22 ago. 2017.

- Traça um panorama histórico da medicalização do parto no período entre as duas guerras (1919-1939) na França. Mostra como, em um contexto de fraca natalidade, produziu-se, nas grandes cidades, a transferência de um número crescente de parturientes para as maternidades hospitalares que ofereciam cada vez mais segurança. Desenvolve-se então uma rede de consultas pré e pós-natais para acompanhar a gravidez e os cuidados com os bebês. O objetivo era salvar as mães e, sobretudo, as crianças. No entanto, tal objetivo foi apenas parcialmente alcançado, porque a medicalização do parto e da função materna encontrou resistências e limites.

173. TORNQUIST, Carmen Susana. Armadilhas da Nova Era: natureza e maternidade no ideário da humanização do parto. Revista Estudos Feministas, v.10, n.2, p.483-492. 2002. Disponível em: <http://www.scielo.br/ scielo.php?script=sci_arttext\&pid=S0104-026X2002000200016\&lng=pt\&nrm=iso\&tlng=pt $>$. Acesso em: 22 ago. 2017.

- Caracteriza brevemente o Movimento pela Humanização do Parto e do Nascimento no Brasil, o qual tem buscado promover modificações na assistência ao parto e ao nascimento, sobretudo no âmbito da saúde coletiva. Busca também refletir sobre as noções de natureza e maternidade, centrais no ideário do movimento, bem como os limites de uma noção de empoderamento das mulheres nesse contexto.

174. TORNQUIST, Carmen Susana. Humanização do parto: entrevista com Robbie Davis-Floyd. Revista Estudos Feministas, v.10, n.2, p.389-397. 2002. Disponível em: <http://www.scielo.br/scielo.php?script=sci_ arttext\&pid=S0104-026X2002000200008\&lng=pt\&nrm=iso\&tlng=pt>. Acesso em: 21 ago. 2017.

- Apresenta entrevista feita com a antropóloga e ativista do parto natural Robbie Davis-Floyd, em Florianópolis, durante a Conferência Ecologia do Parto e do Nascimento, realizada 
simultaneamente no Rio de Janeiro e em Santa Catarina. A conferência foi promovida, entre outras entidades, pela Rede Nacional de Humanização do Parto e do Nascimento (ReHuNa), com a qual a entrevistada tem estabelecido uma intensa relação nos últimos anos.

175. TORNQUIST, Carmen Susana. Paradoxos da humanização em uma maternidade no Brasil. Cadernos de Saúde Pública, v.19, supl.2, p.S419-S427. 2003. Disponível em: <http://www.scielo.br/scielo.php?script=sci_ arttext\&pid=S0102-311X2003000800023\&lng=pt\&nrm=iso >. Acesso em: 22 ago. 2017.

- Analisa as diferenças relativas ao público que acorre à maternidade do Hospital Universitário, em Florianópolis: mulheres de classes médias e de grupos populares. A análise busca observar as diferenças entre essas usuárias no que tange à escolha de acompanhante e às experiências de dor e de amamentação. Essa maternidade procura seguir as recomendações da Organização Mundial da Saúde no sentido da humanização da assistência ao parto.

176. TSUNECHIRO, Maria Alice; RIESCO, Maria Luiza Gonzalez; OGUISSO, Taka. Maria Lucia Mott e a parceria com a enfermagem e a obstetrícia. Cadernos de História da Ciência, v.7, n.2, p.111-115. 2011. Disponível em: <http:// periodicos.ses.sp.bvs.br/scielo.php?script=sci_arttext\&pid=S1809-76342011000200008\&lng=pt\&nrm=i so >. Acesso em: 16 set. 2017.

- Apresenta o relato de participação no Seminário Maria Lucia Mott, realizado em 27 de setembro de 2011, no Instituto Butantan, o qual aborda alguns aspectos da parceria entre a historiadora Maria Lucia Mott e a Escola de Enfermagem da Universidade de São Paulo (EEUSP) na construção do conhecimento histórico sobre o ensino e a prática de obstetrizes e enfermeiras e acerca da assistência ao parto em São Paulo.

177. VARGENS, Octavio Muniz da Costa; PROGIANTI, Jane Márcia; SILVEIRA, Anna Carolina Ferreira da. O significado de desmedicalização da assistência ao parto no hospital: análise da concepção de enfermeiras obstétricas. Revista da Escola de Enfermagem da USP, v.42, n.2, p.339-346. 2008. Disponível em: <http://www.scielo.br/ scielo.php?script=sci_arttext\&pid=\$0080-62342008000200018\&lng=pt\&nrm=iso\&tlng=pt $>$. Acesso em: 28 ago. 2017.

- Discute o processo de construção do significado de desmedicalização para enfermeiras obstétricas. Foram entrevistadas oito enfermeiras obstétricas atuantes no ensino, pesquisa e/ou assistência ao parto que adotam a proposta desmedicalizadora como orientação da sua prática. O respeito à fisiologia, bem como não usar desnecessariamente práticas intervencionistas como rotina constituíram princípios da desmedicalização. A reflexão sobre sua vida e a caracterização da prática obstétrica hospitalar como medicalizada fizeram parte do processo mental das enfermeiras na desconstrução das habilidades adquiridas no modelo biomédico.

178. VARGENS, Octavio Muniz da Costa; SILVA, Alexandra Celento Vasconcellos da; PROGIANTI, Jane Márcia. Contribuição de enfermeiras obstétricas para consolidação do parto humanizado em maternidades no Rio de Janeiro-Brasil. Escola Anna Nery, v.21, n.1, e20170015. 2017. Disponível em: <http://www.scielo.br/scielo. php?script=sci_arttext\&pid=S1414-81452017000100215\&lng=pt\&nrm=iso\&tlng=pt>. Acesso em: 16 set. 2017. - Identifica as práticas empregadas por enfermeiras obstétricas na assistência ao parto em maternidades públicas e sua contribuição na consolidação da humanização do parto e nascimento. Estudo descritivo, quantitativo, transversal, conduzido em maternidades da rede pública municipal do Rio de Janeiro. Como conclusão, identificou-se que as práticas mais utilizadas foram aquelas que não interferem na fisiologia, contribuindo para a humanização. Entretanto, a presença de práticas intervencionistas reflete um processo ainda em transformação.

179. VASCONCELOS, Michele de Freitas Faria de; MARTINS, Cátia Paranhos; MACHADO, Dagoberto de Oliveira. Apoio institucional como fio condutor do Plano de Qualificação das Maternidades: oferta da Política Nacional de Humanização em Defesa da Vida de Mulheres e Crianças Brasileiras. Interface - Comunicação, Saúde, Educação, v.18, supl.1, p.997-1.011. 2014. Disponível em: <http://www.scielo.br/scielo.php?script=sci_ arttext\&pid=S1414-32832014000500997\&lng=pt\&nrm=iso >. Acesso em: 14 set. 2017. 
- Analisa a relação entre função, apoio institucional e humanização, valendo-se da experiência realizada no Plano de Qualificação de Maternidades (PQM), para o qual a contribuição da Política Nacional de Humanização centrou-se justamente no objetivo de desenhar a função apoio institucional. Tendo por base o entendimento de que, para mudar o modelo de atenção e de gestão ao parto e nascimento, é preciso interferir em práticas de saúde "desumanizadoras", no PQM o apoio institucional se constituiu como fio condutor, cujo escopo foi o de, por meio da criação de espaços coletivos de análise e interferência nas práticas, tecer uma rede coletiva de produção de saúde materna e infantil.

180. VELHO, Manuela Beatriz; OLIVEIRA, Maria Emília de; SANTOS, Evanguelia Kotzias Atherino dos. Reflexões sobre a assistência de enfermagem prestada à parturiente. Revista Brasileira de Enfermagem, v.63, n.4, p.652-659. 2010. Disponível em: <http://www.scielo.br/scielo.php?script=sci_arttext\&pid=S0034$71672010000400023 \&$ lng=pt\&nrm=iso\&tlng=pt $>$. Acesso em: 11 set. 2017.

- Busca identificar o estado da arte da produção publicada sobre atuação da enfermeira obstétrica no processo do nascimento, contribuir para futuras investigações e auxiliar nas reflexões sobre essa temática. Foi feito levantamento bibliográfico no Lilacs, Medline, Biblioteca Cochrane, Scielo. Descritores utilizados: enfermeiras obstétricas, trabalho de parto, parto, assistência de enfermagem. Temas selecionados: regulamentação da profissão; atendimento; assistência prestada; vínculo estabelecido; ações educativas; atividades administrativas; dificuldades.

181. VELHO, Manuela Beatriz; SANTOS, Evanguelia Kotzias Atherino dos; COLLAÇO, Vânia Sorgatto. Parto normal e cesárea: representações sociais de mulheres que os vivenciaram. Revista Brasileira de Enfermagem, v.67, n.2, p.282-289. 2014. Disponível em: <http://www.scielo.br/scielo.php?script=sci_arttext\&pid=S0034$71672014000200282 \&$ Ing=pt\&nrm=iso\&tlng=pt $>$. Acesso em: 15 set. 2017.

- Busca conhecer as representações sociais do parto normal e da cesárea de mulheres que os vivenciaram. Foram realizadas entrevistas com mulheres que tiveram a vivência de ambas as vias de parto. Os resultados revelam representações como: a busca de informações; o vivenciar da parturição sozinha versus acompanhada; e a mulher não tem opção de escolha. O parto normal engloba temas como: ambivalência de sentimentos; percepção positiva e hospitalização. A cesárea está relacionada com ambivalência de sentimentos, a solução de um problema e a preferência pela cesárea.

182. VELHO, Manuela Beatriz; SANTOS, Evanguelia Kotzias Atherino dos; BRÜGGEMANN, Odaléa Maria; CAMARGO, Brígido Vizeu. Vivência do parto normal ou cesáreo: revisão integrativa sobre a percepção de mulheres. Texto \& Contexto - Enfermagem, v.21, n.2, p.458-466. 2012. Disponivel em: <http://www.scielo.br/ scielo.php?script=sci_arttext\&pid=S0104-07072012000200026\&lng=pt\&nrm=iso\&tlng=pt $>$. Acesso em: 13 set. 2017.

- Identifica a contribuição das pesquisas desenvolvidas, em âmbito nacional e internacional, sobre a percepção do parto normal e cesáreo pelas mulheres que os vivenciaram. A busca dos artigos ocorreu nas bases de dados Medline, Lilacs, Bdenf, Cinahl e Indexpsi, no período de 2000 a 2009. Os estudos apresentam percepções positivas e negativas das mulheres acerca dos dois tipos de parto, tais como o protagonismo da mulher e a melhor recuperação no parto normal, a ausência de dor na cesárea, a insatisfação com a assistência recebida; assim como recomendações para a prática obstétrica e sugestão de novas pesquisas.

183. WINCK, Daniela Ries; BRÜGGEMANN, Odaléa Maria; MONTICELLI, Marisa. A responsabilidade profissional na assistência ao parto: discursos de enfermeiras obstétricas. Escola Anna Nery, v.16, n.2, p.363-370. 2012. Disponível em: <http://www.scielo.br/scielo.php?script=sci_arttext\&pid=S1414-81452012000200022\&lng $=$ pt\&nrm=iso\&tlng=pt $>$. Acesso em: 13 set. 2017.

- Procura identificar o conhecimento das enfermeiras obstétricas em relação à responsabilidade profissional na assistência ao parto. Foram entrevistadas 11 enfermeiras que atuavam na 
assistência ao parto em hospitais e/ou domicílio no estado de Santa Catarina, entre março e agosto de 2009. Verificou-se que as enfermeiras conhecem pouco a respeito das repercussões legais do erro. Ao assumir a assistência ao parto, devem dedicar total atenção aos limites da competência e à prevenção de erros previsíveis, tendo em mente que assumirão também a responsabilização por suas falhas.

184. WOLFF, Leila Regina; WALDOW, Vera Regina. Violência consentida: mulheres em trabalho de parto e parto. Saúde e Sociedade, v.17, n.3, p.138-151. 2008. Disponivel em: <http://www.scielo.br/scielo.php?script=sci_ arttext\&pid=S0104-12902008000300014\&lng=pt\&nrm=iso\&tlng=pt >. Acesso em: 28 ago. 2017.

- Procura denunciar como se dá a assistência em muitas das instituições de saúde e revela como várias das circunstâncias a que a mulher está sujeita no processo de parturição se caracterizam por ações de não cuidado e/ou como desumanização. Os relatos das parturientes evidenciaram um tipo especial de violência de gênero na área da saúde, uma violência consentida, conforme opinião das autoras, que ocorre com mulheres em trabalho de parto e parto.

185. YAZLLE, Marta Edna Holanda Diógenes; ROCHA, Juan Stuardo Yazlle; MENDES, Maria Célia; PATTA, Maristela Carbol; MARCOLIN, Alessandra Cristina; AZEVEDO, George Dantas de. Incidência de cesáreas segundo fonte de financiamento da assistência ao parto. Revista de Saúde Pública, v.35, n.2, p.202-206. 2001. Disponível em: $<$ http://www.scielo.br/scielo.php?script=sci_arttext\&pid=\$0034-89102001000200015\&lng=pt\&nrm=iso\&tl $\mathrm{ng}=\mathrm{pt}>$. Acesso em: 4 set. 2017.

- A partir dos dados de um sistema de informações hospitalares, foi feita uma análise retrospectiva dos partos ocorridos no município de Ribeirão Preto (SP), no período de 1986-1995, com o objetivo de estudar os tipos de partos de acordo com a categoria de internação da paciente, bem como as indicações de cesarianas mais frequentemente referidas. A incidência de cesariana variou segundo a categoria de internação, observando-se um gradiente crescente à medida que se elevou o padrão social das gestantes, não havendo correspondência com o risco obstétrico.

186. ZVEITER, Marcele; SOUZA, Ivis Emília de Oliveira. Solicitude constituindo o cuidado de enfermeiras obstétricas à mulher-que-dá-à-luz-na-casa-de-parto. Escola Anna Nery, v.19, n.1, p.86-92. 2015. Disponível em: $<$ http://www.scielo.br/scielo.php?script=sci_arttext\&pid=S1414-81452015000100086\&lng=pt\&nrm=is o\&tlng=pt>. Acesso em: 15 set. 2017.

- Analisa a constituição do cuidado de enfermeiras obstétricas à mulher que dá à luz na casa de parto. O fio condutor da hermenêutica se sustenta na compreensão vaga e mediana das enfermeiras obstétricas. Como contribuição, da e para a enfermagem obstétrica, apresenta-se a hermenêutica da consideração e da paciência fundada no conceito de solicitude e inerente ao movimento existencial das enfermeiras.

187. ZVEITER, Marcele. O que pode ser traumático no nascimento? Revista Latinoamericana de Psicopatologia Fundamental, v.8, n.4, p.706-720. 2005. Disponível em: <http://www.scielo.br/scielo.php?script=sci_ arttext\&pid=S1415-47142005000400706\&lng=pt\&nrm=iso\&tlng=pt>. Acesso em: 6 set. 2017.

- Procura as respostas para o que pode ser traumático no nascimento, percorrendo as pontes entre o cuidado exercido na cena do parto e as primeiras experiências do bebê. O objetivo é discutir o trauma em relação ao modo de cuidar na cena do nascimento. A relevância do tema repousa sobre a relação entre a qualidade das experiências iniciais e um desenvolvimento saudável. A conclusão é que o modo de assistir ao parto pode deixar marcas psíquicas importantes, influenciando diretamente no cuidado materno e sendo, portanto, um risco para trauma no nascimento. 